Received Date : 19-Feb-2017

Revised Date : 07-Apr-2017

Accepted Date : 18-Apr-2017

Article type : Original Article

Running head recto: Two new species of Paraphoma

Running head verso: A. Moslemi et al.

\title{
Paraphoma chlamydocopiosa sp. nov. and Paraphoma pye sp. nov., two new species associated with leaf and crown infection of pyrethrum
}

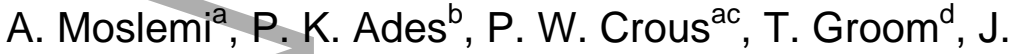
B. Scott ${ }^{\mathrm{e}}, \mathrm{M}$. E. Nicolas ${ }^{\mathrm{a}}$ and
P. W. J. Taylor ${ }^{\mathrm{a} *}$

${ }^{a}$ Faculty of Veterinary and Agricultural Sciences, University of Melbourne, Victoria, 3010; ' School of Ecosystem and Forest Sciences, University of Melbourne, Victoria, 3010, Australia; ' Westerdijk Fungal Biodiversity Institute, Utrecht, Netherlands; ${ }^{\mathrm{d} B o t a n i c a l}$ Resources Australia Pty Ltd, Ulverstone, Tasmania, 7315; and ${ }^{\mathrm{e}}$ Tasmanian Institute of Agriculture, University of Tasmania - Cradle Coast Campus, Burnie, Tasmania, 7320, Australia

*E-mail: paulwjt@unimelb.edu.au

Two new pathogens of pyrethrum, described as Paraphoma chlamydocopiosa and Paraphoma pye, isolated from necrotic leaf lesions on pyrethrum plants in northern Tasmania, Australia, were identified using morphological characters, phylogenetic analysis of This is the author manuscript accepted for publication and has undergone full peer review but has not been through the copyediting, typesetting, pagination and proofreading process, which may lead to differences between this version and the Version of Record. Please cite this article as doi: $10.1111 /$ ppa.12719

This article is protected by copyright. All rights reserved 
the internal transcribed spacer (ITS), elongation factor 1- $\alpha(E F 1-\alpha)$ and $\beta$-tubulin (TUB) genes, and pathogenicity bioassays. Bootstrap support in the combined and individual gene region phylogenetic trees supported the two species that were significantly different from the closely related $P$. chrysanthemicola and $P$. vinacea. Morphological characteristics also supported the two new species, with conidia of $P$. chlamydocopiosa being considerably longer and wider than either $P$. chrysanthemicola or $P$. vinacea, and $P$. pye being distinct in forming bilocular pyenidia. Glasshouse pathogenicity tests based on root dip inoculation resulted in P. chlamydocopiosa and P. pye infecting the crown and upper root tissues of pyrethrum plants, and significant reduction in biomass 2 months after inoculation. Both of these Paraphoma species caused leaf lesions during in vitro and in vivo bioassays 2 weeks after foliar spray inoculation. Although P. chlamydocopiosa and P. pye were shown to be crown rot pathogens, they were also commonly isolated from leaves of diseased plants in pyrethrum fields of northern Tasmania.

Keywords: bilocular pycnidia, longer conidia, Paraphoma chlamydocopiosa, Paraphoma pye, pathogenicity, phylogenetic analysis

\section{Introduction}

Pyrethrum (Tanacetum cinerariifolium) is a perennial in the Asteraceae that has been widely used for pyrethrin production. Insecticidal pyrethrins are extracted from the achenes within the flower heads (Grdisa et al., 2009). The majority of the world's production of natural pyrethrins occurs in Victoria and northern Tasmania. The crop is spring sown, with its first harvest occurring approximately 15 months after establishment and up to three subsequent annual harvests thereafter (Vaghefi et al., 2016).

Many foliar and soilborne diseases of pyrethrum affect flower production and regrowth potential. The most important foliar diseases of pyrethrum are ray blight caused by Stagonosporopsis tanaceti (Vaghefi et al., 2016; Bhuiyan et al., 2017), tan spot that is predominantly caused by Didymella tanaceti (Pearce et al., 2015), anthracnose caused by Colletotrichum tanaceti (Barimani et al., 2013) and sclerotinia flower blight caused by Sclerotinia minor (O’Malley et al., 2015). Soilborne pathogens of pyrethrum include sclerotinia crown rot caused by S. sclerotiorum (Pethybridge et al., 2008), Paraphoma vinacea that causes crown rot and reduced growth in yield decline-affected fields of northern 
Tasmania (Moslemi et al., 2016), and Fusarium oxysporum and F. avenaceum associated with yield decline of pyrethrum (Moslemi et al., 2017).

The taxon Paraphoma was originally introduced as a section of the genus Phoma, but was later raised to a genus distinguished by production of setose pycnidia and dictyochlamydospores (Aveskamp et al., 2010; De Gruyter et al., 2013). However, based on phylogenetic studies several species were also allocated to genera in closely related families such as Coniothyriaceae, Cucurbitariaceae and Phaeosphaeriaceae (Chen et al., 2015).

Paraphoma species have been identified mainly as soilborne pathogens, causing root and crown rot diseases in temperate areas of Australia, America and Eurasia (Boerema et al., 2004; De Gruyter et al., 2013; Moslemi et al., 2016). The type species, P. radicina, was first identified on roots of Prunus cerasus in 1901 in Australia (De Gruyter et al., 2010). Paraphoma radicina was also isolated from Malus sylvestris in the Netherlands and Lycopersicon esculentum (now Solanum lycopersicum) in Germany in 1907 (De Gruyter et al., 2010). The type isolate of Paraphoma fimeti was isolated from soil and recovered from the roots of Juniperus communis in 1991 in Switzerland (De Gruyter et al., 2010). Paraphoma chrysanthemicola was the first member of Paraphoma reported on plants of other Compositae (De Gruyter et al., 2010). Srivastava (1953) also reported this species as a pathogen of Chrysanthemum sp. Roots of Chrysanthemum morifolium were found to be infected with $P$. chrysanthemicola in 1967 in Germany (De Gruyter et al., 2010). Later, Dorenbosch (1970) reported $P$. chrysanthemicola as a root pathogen of florists' Chrysanthemum. Other Paraphoma species have also been reported to be pathogens of Compositae such as C. morifolium and Cichorium intybus, and Calluna vulgaris (Ericaceae) (Ge et al., 2016). Hay et al. (2015) reported P. chrysanthemicola as a pathogen causing necrotic leaf spots at low frequency in pyrethrum fields of northern Tasmania. However, the existence and pathogenicity of $P$. chrysanthemicola to pyrethrum in Australia was not verified.

This research describes two new Paraphoma species isolated from pyrethrum leaf lesions in northern Tasmania, Australia using taxonomic and multigene phylogenetic studies and assesses pathogenicity of these species in pyrethrum as foliar and crown pathogens.

\section{Materials and methods}




\section{Isolates}

Sixteen Paraphoma isolates were selected from different geographical locations in northern Tasmania. This included four Paraphoma isolates (BRIP 65168, BRIP 65169, BRIP 65170 and BRIP 65171) isolated from leaf lesions by N. Vaghefi in 2013 from pyrethrum plants at Table Cape and eight isolates collected by T. Pearce, F. Hay and J. Scott between 2012 and 2014 from pyrethrum leaf lesions (BRIP 57988, BRIP 57989, BRIP 65173, BRIP 65174, BRIP 65176, BRIP 65177, BRIP 65178 and BRIP 65179), which were identified at that time to be $P$. chrysanthemicola by Hay et al. (2015). Four $P$. vinacea isolates (BRIP 63684, BRIP 63683, BRIP 63682 and BRIP 63685) collected by A. Moslemi in 2014 from infected crown tissues of yield-decline affected pyrethrum plants at Devonport were also included. Details of the sites and collectors have been provided in Table 1. Sequences of five P. fimeti isolates, CBS 164.31, CBS 119754, CBS 258.68, CBS 550.70 and CBS 379.67, received from Westerdijk Fungal Biodiversity Institute (CBS), Utrecht, Netherlands were also included. Other reference sequences used in the phylogenetic analyses were downloaded from GenBank at http://www.ncbi.nlm.nih.gov/ (Table 2).

\section{Morphological analysis}

One representative isolate from each of the phylogenetic clades of the Tasmanian Paraphoma were examined for their morphological characteristics. Isolates were examined for growth rate on oatmeal agar (OA), malt extract agar (MEA), cherry decoction agar (CHA), potato dextrose agar (PDA) and V8 juice agar (V8) (Crous et al., 2009), after 7 days' incubation according to the conditions described by Boerema et al. (2004). Three replicates per isolate were used. Colony colour was assessed on all media after 2 weeks using Rayner's colour chart (Rayner, 1970).

Additionally, all isolates grown on CHA, OA and MEA for 14 days at $20-22{ }^{\circ} \mathrm{C}$ and under the light regime according to Boerema et al. (2004) were examined for the production of pycnidia and conidia. Two isolates (BRIP 65168 and 65170), which did not produce pycnidia on these media, were also grown on PDA and V8 to induce pycnidial production. Pycnidia were examined for the presence/absence of setae and/or ostioles. The pycnidial cell wall anatomy was observed by sectioning individual pycnidia using a RM2125 RTS microtome (Leica) as described by Moslemi et al. (2016). Conidial shape and dimensions 
(length $\times$ width) were also recorded. In each measurement, 30 replicates of each fungal structure were measured from samples mounted in clear lactic acid (Aveskamp et al., 2010) using a DM-2900 (Leica) compound microscope. Microscopic images were captured with differential interference contrast and bright-field illumination.

In addition, to determine the E metabolite production and cell wall anatomy of isolates, $1 \mathrm{M} \mathrm{NaOH}$ and iodine reaction tests were carried out, respectively, according to Boerema et al. (2004) and Phoma methodologies (http://www.q-bank.eu).

\section{PCR and sequencing}

Total genomic DNA was extracted from mycelium scraped directly from 7-day-old, singlespored cultures grown on OA using the DNeasy Plant Mini kit (QIAGEN) following the manufacturer's instructions. All PCR amplifications for ITS, TUB and EF1 were performed in a MyCycler thermal cycler (Bio-Rad) with a total reaction volume of $12.5 \mu \mathrm{L}$ according to Moslemi et al. (2016). The PCR cycling conditions and product purifications were performed as described in Moslemi et al. (2016). Agarose gels were stained with a SYBR Safe DNA gel stain and visualized with a GelDoc (Bio-Rad) after electrophoresis.

Purified amplicons from each gene region were sequenced at the Australian Genome Research Facility Ltd, Melbourne, Australia. Amplicons were sequenced in both the forward and reverse sense using the same set of primers on a 3730xl DNA Analyzer (Applied Biosystems) and with BigDye Terminator v. 3.1 chemistry. Sequences of related genera for ITS, TUB and EF1 were downloaded from the GenBank nucleotide database (Table 2). Consensus sequences were obtained from both forward and reverse sequences using the DENOVO assembly option and pairwise aligned with the CLUSTALW algorithm within GENEIOUS v. 7.1.9 (Biomatters Ltd.) (Kearse et al., 2012) and annotated with the most similar gene sequences of Paraphoma species obtained from NCBI database within GENEIOUS.

Sequences were submitted to GenBank and descriptions of nomenclature to MycoBank (Crous et al., 2004).

\section{Phylogenetic analysis}


Maximum likelihood (ML) and neighbour-joining (NJ) phylogenetic trees were constructed for each gene individually and combined using GENEIOUS TREE BUILDER for NJ analysis within GENEIOUS and PHYML for ML analysis (Guindon \& Gascuel, 2003). A general timereversible with invariant sites and gamma distributed rates across sites $(\mathrm{GTR}+\mathrm{I}+\mathrm{G})$ was determined as the best nucleotide substitution model for ML analysis in PAUP v. 4.0a151 (Swofford, 2003) based on the Akaike information criterion (AIC) and Bayesian information criterion (BIC) with 500 bootstrap replicates as default. Gaps were treated as missing data. For the NJ analysis, the Tamura-Nei substitution model (Tamura et al., 2013) was selected as the best fit model with gamma distributed $(\mathrm{G})$ rate among sites and pairwise deletion of the gaps using MEGA 6 (Tamura et al., 2013) with 1000 bootstrap replicates to assess the relative stability of branches and comparing the AIC and BIC estimates. Congruence of the trees for each pair of genes was confirmed online at http://max2.ese.u-psud.fr/icong/index.help.html before concatenation and generating the combined phylogenetic tree (de Vienne et al., 2007). GenBank accession numbers for reference markers EF1, TUB and ITS were derived from Quaedvlieg et al. (2013). Sequence alignments of $P$. chlamydocopiosa and $P$. pye (12 isolates) and combined phylogenetic trees were deposited in TreeBASE at www.treebase.org as submission 20959.

\section{Pathogenicity tests}

Pathogenicity of Paraphoma species isolated from pyrethrum plants was assessed in two experiments using root dip and foliar spray inoculation methods. For each experiment, seedlings of cultivar Pyrate were germinated from steam-sterilized seeds and raised in seedling mix in Tasmania at Botanical Resources Australia (BRA). Seedlings were transferred to $10 \mathrm{~cm}$ diameter pots with potting mix (Debco), fertilized with $5 \mathrm{~g}$ Osmocote Plus (Scotts Australia Pty Ltd) per pot and grown in a glasshouse for 2 months at $25-27^{\circ} \mathrm{C}$ under natural light.

Inoculum was prepared from newly grown, single-spored cultures on PDA, by adding $10 \mathrm{~mL}$ sterile water to each plate and gently scraping the colony surface with a glass spreader and then filtering the spore suspension through cheesecloth. The concentration of each spore suspension was quantified to $10^{6}$ spores $\mathrm{mL}^{-1}$ using a haemocytometer (Moslemi et al., 2016). Two drops of $0.1 \%$ Tween 20 solution was added to each spore suspension to increase the ability of the spores to adhere to the surface of the inoculated tissue. 


\section{Root inoculation}

Isolates BRIP 65168 and BRIP 65169 were chosen as representatives of all other isolates of the respective phylogenetic groups in this experiment based on the morphological similarities with other species in each clade. Holotype isolate $P$. vinacea BRIP 63684 was also included in the experiment for comparison. The pathogenicity experiment was conducted in duplicate.

In both experiments, 10 pyrethrum plants per treatment were root dip inoculated with the spore suspension for each isolate. Pyrethrum plants were uprooted and roots washed under tap water for $10 \mathrm{~min}$ to remove excess soil. Roots were then immersed in $100 \mathrm{~mL}$ of the spore suspension for $10 \mathrm{~min}$. Thereafter, they were transplanted into $10 \mathrm{~cm}$ diameter pots and maintained in a glasshouse for 2 months. Controls were inoculated with sterile water but otherwise treated identically. To prevent cross contamination between treatments by airborne dispersal of spores, all experiments were carried out in a nonrandomized design with no random placement of the plants within treatments. True replication was achieved by repeating the experiments. The distance between different treatments was at least $70 \mathrm{~cm}$ and drip irrigation was used to minimize splash dispersal of spores.

Two months after inoculation, individual plants $(n=10$ per treatment $)$ were removed from each pot and roots were washed under tap water to remove the excess soil. They were then transferred to the laboratory for sectioning. Tissue sectioning and surface sterilization were carried out as described by Moslemi et al. (2016). Sterilized tissues were subsequently cultured onto water agar (WA). After 4 days' incubation at $22-24{ }^{\circ} \mathrm{C}$, colonies growing on WA were subcultured onto OA for identification (Crous et al., 2009). Oatmeal agar plates were incubated at $22-24{ }^{\circ} \mathrm{C}$ in the dark for 7 days and then under a $13 \mathrm{~h}$ photoperiod with $\mathrm{UV}$ and white fluorescent light for 7 days (Boerema et al., 2004).

After sampling and reisolation of the pathogen, the remaining plants $(n=10$ per treatment) were sectioned into petioles and leaves (above ground), and crown and root (below ground). Plant samples were dried in an oven for 3 days at $71{ }^{\circ} \mathrm{C}$ and then weighed.

\section{Leaf and petiole inoculation}

Three replicates per treatment of healthy rosette stage Pyrate plants were spray inoculated with $20 \mathrm{~mL}$ (each plant) of $10^{6}$ spores $\mathrm{mL}^{-1}$ spore suspension of each isolate (BRIP 65168, BRIP 65169 and BRIP 63684); control plants were sprayed with water. A hand sprayer was used to spray the leaves with inoculum until just before runoff. Each plant was then covered 
with a plastic bag for $24 \mathrm{~h}$ to increase humidity after inoculation, to encourage spore germination and infection. Covers were then removed and plants were maintained in the glasshouse for 14 days until leaf lesions developed on the leaves. Any leaf with the lesions developed on both sides was detached and cultured for fungal identification during this period. Tissue surface sterilization and culturing were carried out as previously described. A DM205 FA stereomicroscope (Leica) was used to assess the disease symptoms.

In addition, an in vitro inoculation test with surface-sterilized detached petioles of healthy pyrethrum plants was carried out using the same isolates, by pipetting $10 \mu \mathrm{L}$ of a $10^{6}$ spores $\mathrm{mL}^{-1}$ suspension of each isolate onto the leaves and petioles. Controls were treated with sterile water. Detached petioles were incubated in plastic containers, four petioles per container, with moistened filter papers at $21{ }^{\circ} \mathrm{C}$ for 8 days. Symptoms were assessed after 8 days by observing the petioles under a dissecting microscope and tissue infection was confirmed by culturing the surface sterilized leaf tissues on WA and then subculturing onto OA. Both invivo and in vitro tests were repeated.

\section{Dry weight data analyses}

Dry weight data (above ground, below ground and total) analyses were performed using a mixed model with the MIXED procedure in SAS v. 9.4 (SAS Institute Inc.) and applying the residual maximum likelihood (REML) estimation method. This permitted data from both experiments to be combined in one analysis. Noninfected plants, as determined by isolations, were removed from the data. Comparison of means was performed by pairwise $t$-tests $(\alpha=$ 0.05). SAS was used for all analyses. The linear mixed model fitted was:

$\mathrm{Y}_{\mathrm{ijk}}=\mu+\tau_{\mathrm{i}}+\gamma_{\mathrm{j}}+\tau \gamma_{\mathrm{ij}}+\varepsilon_{\mathrm{ijk}}$

where $\mu$ is the overall mean, $\tau_{\mathrm{i}}$ is the fixed effect of treatment $\mathrm{i}, \gamma_{\mathrm{j}}$ is the random effect of trial $\mathrm{j}, \tau \gamma_{\mathrm{ij}}$ is the random interaction between treatment $\mathrm{i}$ and trial $\mathrm{j}$ and $\varepsilon_{\mathrm{ijk}}$ is an independent random error. The variable $\varepsilon$ is assumed to be normally distributed, with fixed variance within a trial, but may vary between trials. The interaction between treatment and trial $\left(\tau \gamma_{\mathrm{ij}}\right)$ was not significant by likelihood ratio test and hence was deleted from the final model. Data for plants that were inoculated but not confirmed to be infected were omitted from the analysis. This resulted in an unbalanced design. 


\section{Results}

\section{Phylogeny}

Nucleotide sequences of 31 isolates were used in the three gene phylogenetic analyses. The congruence test between each pair of loci showed all to be congruent and hence all three genes could be included in the combined phylogenetic analysis $(P<0.001)$. Moreover, a congruence test between the NJ and ML phylogenetic trees showed tree topologies were identical and trees were more congruent than expected under random chance $(P<0.001)$.

In individual PHYML trees of ITS and TUB, BRIP 65169 and BRIP 65171 clustered with $P$. vinacea with $88 \%$ and $80 \%$ bootstrap support, respectively. However, in the tree constructed for EF 1 the two isolates clustered with $P$. chrysanthemicola with $88 \%$ bootstrap support. All other isolates (BRIP 65168 to BRIP 65179, BRIP 57988 and BRIP 57989) clustered in a separate monophyletic group with bootstrap values of $94 \%, 84 \%$ and $73 \%$ for ITS, $E F 1$ and $T U B$, respectively (individual trees are not shown). In the combined PHYML phylogenetic tree of ITS-TUB-EF1, a total of 828 (ITS: 373, EF1: 263, TUB: 192) characters in the final dataset were obtained including 618 (ITS: 297, EF1: 179, TUB: 142) constant characters, 155 (ITS: 57, EF1: 54, TUB: 44) parsimony informative characters and 55 uninformative variable characters. The three-gene phylogeny consisting of ITS, TUB and EF1 showed two new species of Paraphoma in well-supported monophyletic clades, distinct from the previously described Paraphoma species. In the combined PHYML maximum likelihood phylogenetic tree, BRIP 65168 and BRIP 65170, which were recovered from leaf lesions in 2013 in Table Cape, clustered with the eight Paraphoma isolates including BRIP 65172 to BRIP 65179 and BRIP 57988 and BRIP 57989, collected from the leaf lesions between 2012 and 2014 in different geographical locations of northern Tasmania (Table 1), with 99\% bootstrap support in PHYML and 100\% support in NJ trees phylogenetic analyses. Two isolates, BRIP 65169 and BRIP 65171, fell in the same group as P. chrysanthemicola and $P$. vinacea, but formed a clade distinct from both these species in both the PHYML and NJ trees (Fig. 1). Neighbour-joining bootstrap values are shown where they differ from the PHYML values. Isolates BRIP 57988 and BRIP 57989 were previously used to identify $P$. chrysanthemicola by Hey et al. (2015) (BRIP accession numbers were assigned subsequent to the publication by Hey et al., 2015). 


\section{Morphology and taxonomy}

Morphological traits differentiated the Paraphoma isolates into two distinct groups. Assignment of individuals to these groups matched perfectly the groups from the phylogenetic analyses, confirming that the Paraphoma isolated from leaf lesions of pyrethrum plants in the fields of northern Tasmania were two new species. The names Paraphoma chlamydocopiosa and Paraphoma pye are proposed for these. All isolates were compared with the type specimen of $P$. chrysanthemicola, and the ex-holotype strain $P$. vinacea.

\section{क}

Paraphoma chlamydocopiosa sp. nov. A. Moslemi \& P.W.J. Taylor, sp. nov.

\section{MycoBank: MB819496}

Etymology: Named after the abundant production of chlamydospores on CHA and PDA; chlamydocopiosa $=$ chlamydo (chlamydospore) and copiosa (abundant) in Latin.

\section{Morphological and cultural characteristics}

\section{On PDA}

Colony diameter $17.5 \mathrm{~mm}$ after 1 week; aerial mycelium compact, white to greyish. Colony pigmentation after 2 weeks olivaceous grey with pale vinaceous margins. Reverse pale vinaceous to black in the centre. Margins regular.

Conidiomata pycnidial, ostiolate, unilocular and solitary, submerged in agar, mostly globose and obpyriform, brown to dark brown; $140-150 \mu \mathrm{m}$ diam. and setose. Conidial matrix buff; pycnidial cell wall $15 \mu \mathrm{m}$ diam., micropycnidia abundant and submerged in the medium, pale to dark brown; 70-104 $\mu \mathrm{m}$ diam. Conidiophores reduced to phialidic conidiogenous cells, hyaline, smooth and ampulliform, 6-7 $\mu \mathrm{m}$ length. Conidia aseptate, ellipsoid to oblong, 3-4 $\times 6-9(\mathrm{SD}=0.31 \times 2.47) \mu \mathrm{m}$. Chlamydospores abundant, occurring mostly in long chains, pale to dark brown, ellipsoid to globose and aseptate, 10-15 $\mu \mathrm{m}$ diam. (Fig. 2).

Sexual morph not observed.

On $V 8$ 
Colony diameter $15 \mathrm{~mm}$ after 1 week; aerial mycelium woolly, silver olivaceous. Colony pigmentation after 2 weeks pale grey olivaceous with thin white margins. Reverse similar. Margins regular. Conidia aseptate, ellipsoid to oblong, $3-5.5 \times 7-9(\mathrm{SD}=0.81 \times 0.61) \mu \mathrm{m}$.

\section{On $O A$}

Colony diameter $17.5 \mathrm{~mm}$ after 1 week; aerial mycelium floccose, green olivaceous. Colony pigmentation after 2 weeks pale olivaceous. Reverse with pale vinaceous rings formed in the centre of the colony. Margins regular.

\section{On MEA}

Colony diameter $12 \mathrm{~mm}$ after 1 week; aerial mycelia white-greyish and floccose. Colony pigmentation after 2 weeks dark grey to black in the centre with pale olivaceous margins. Reverse olivaceous-grey with scarlet red concentric rings in the centre. Margins regular.

\section{On CHA}

Colony diameter $12 \mathrm{~mm}$ after 1 week; aerial mycelium floccose, white to pale green. Colony pigmentation after 2 weeks, dark grey on both sides and pale vinaceous to black in the centre of the reverse side. Margins regular or slightly regular.

\section{Physiological characters}

No change of colour was observed upon application of $1 \mathrm{M} \mathrm{NaOH}$ to mycelium growing on OA (Dorenbosch, 1970; Boerema et al., 2004). No change of colour was observed in cell wall upon application of iodine to squashed pycnidia on PDA, although the cell contents turned red, hence the cell wall type was identified as pseudoparenchymatous (Phoma methodologies, http://www.q-bank.eu).

\section{Specimen examined}

Holotype: Australia, northern Tasmania, Table Cape, from Tanacetum cinerariifolium, 2013, N. Vaghefi (BRIP 65168, culture ex-holotype - UMPc01).

Notes: Differs from P. chrysanthemicola described by Boerema et al. (2004) (conidia (3.5-) 4-5.5 (-6.5) × 1.5-2 (-2.5) $\mu \mathrm{m})$ and $P$. vinacea by Moslemi et al. (2016) by significantly larger conidia on PDA and abundant production of chlamydospores mainly on CHA and PDA. Paraphoma chlamydocopiosa produces red pigmentation on PDA, OA, MEA and CHA 
similar to $P$. vinacea, but with less intensity. Compact colonies of $P$. chlamydocopiosa on PDA, hardly show the vinaceous colour. Paraphoma chrysanthemicola produces yellow pigmentation on OA (Johnston, 1981), which does not occur in cultures of $P$. chlamydocopiosa. Paraphoma chlamydocopiosa colonies produced red pigmentation under UV light. This did not occur with the colonies grown in the dark.

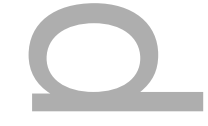

Paraphoma pye sp. nov. A. Moslemi \& P.W.J. Taylor, sp. nov.

MycoBank: MB819470

Etymology: Named after the local colloquial name used to refer to pyrethrum.

Morphological and cultural characteristics

On $O A$

Colony diameter $22 \mathrm{~mm}$ after 1 week; aerial mycelium woolly, white to greyish. Colony pigmentation after 2 weeks dark olivaceous grey in the centre with white thin margins. Reverse grey-green margins turning dark olivaceous towards the centre. Margins regular. Conidiomata pycnidial, ostiolate with long neck, 101-112 $\mu \mathrm{m}$ diam. , uni- or bilocular and solitary; submerged in agar, obpyriform, semipilose, pale to dark brown; 200-267 $\mu \mathrm{m}$ diam. Conidial matrix buff; pycnidial cell wall 10-11.5 $\mu \mathrm{m}$ thick, micropycnidia sparse, submerged in the medium, dark brown. Conidiophores reduced to phialidic conidiogenous cells, hyaline, smooth and ampulliform, 6-10 $\mu \mathrm{m}$ long. Conidia aseptate, ellipsoid to oblong, 3.5-6 × 1.5$3.5(\mathrm{SD}=0.42 \times 0.45) \mu \mathrm{m}$. Chlamydospores abundant, occurring in two types of short and long chains; and pseudosclerotioid chlamydospores (resembling pseudosclerotia forming from aggregation of unicellular chlamydospores) (http://www.q-bank.eu/); pale brown, ellipsoid to globose and aseptate, 6-8.5 $\mu \mathrm{m}$ diam. (Fig. 3).

Sexual morph not observed.

On MEA

Colony diameter $20 \mathrm{~mm}$ after 1 week; aerial mycelia pale grey and woolly. Colony pigmentation after 2 weeks army green in the centre with thin white margins. Reverse, similar 
with dark black pigmentation towards the centre. Margins regular. Conidia aseptate, ellipsoid to oblong, $4-5.5 \times 2-3(\mathrm{SD}=0.31 \times 0.38) \mu \mathrm{m}$.

\section{On $\mathrm{CHA}$}

Colony diameter $16 \mathrm{~mm}$ after 1 week; aerial mycelium woolly, white to pale green. Colony pigmentation after 2 weeks, dark olivaceous on both sides turning black in centre on reverse. Margins regular. Conidia aseptate, ellipsoid to oblong, $3.5-5 \times 1.5-3(\mathrm{SD}=0.25 \times 0.41) \mu \mathrm{m}$.

On PDA

Colony diameter $20 \mathrm{~mm}$ after 1 week and aerial mycelium compact, white to pale grey.

Colony pigmentation dark green with white thin margins averse and black on reverse.

Margins regular.Conidia aseptate, oblong, 3.5-6.5 × 1.5-3 $(\mathrm{SD}=0.54 \times 0.44) \mu \mathrm{m}$.

On $V 8$

Colony diameter $20 \mathrm{~mm}$ after 1 week and aerial mycelium floccose, pale green-grey with white thin and regular margins averse and dark grey reverse. Conidia aseptate, oblong or ellipsoid, $3-6.5 \times 1.5-3(\mathrm{SD}=0.42 \times 0.43) \mu \mathrm{m}$.

\section{Physiological characters}

No change of colour upon application of $1 \mathrm{M} \mathrm{NaOH}$ to mycelium growing on $\mathrm{OA}$

(Dorenbosch, 1970; Boerema et al., 2004). No change of colour was observed in cell wall upon application of iodine to squashed pycnidia on PDA, although the cell contents turned red, hence the cell wall type was identified as pseudoparenchymatous (Phoma methodologies, http://www.q-bank.eu).

\section{Specimen examined}

Holotype: Australia, northern Tasmania, Table Cape, from Tanacetum cinerariifolium, 2013, N. Vaghefi (BRIP 65170, culture ex-holotype UMPp02).

Notes: Differs from P. chrysanthemicola described by Boerema et al. (2004) (conidia (3.5-) 4-5.5 (-6.5) × 1.5-2 (-2.5) $\mu \mathrm{m})$ and P. vinacea by Moslemi et al. (2016) by occasional production of bilocular pycnidia on PDA and CHA. Paraphoma pye produces sclerotioid chlamydospores that also can be produced by the ex-neotype species, $P$. chrysanthemicola. No red pigmentation occurs in the cultures of $P$. pye. Paraphoma chrysanthemicola produces 
yellow pigmentation on OA (Johnston, 1981), which does not occur in cultures of P. pye. The pycnidial cell wall is considerably thinner than that of $P$. vinacea and the ostioles have elongated necks.

\section{Pathogenicity tests \\ Root inoculation}

All Paraphoma isolates significantly reduced growth of pyrethrum plants after root dip inoculation

All three Paraphoma species were able to cause upper root and crown infection, while basal petiole infection also occurred in plants inoculated with $P$. pye and $P$. vinacea. The disease incidence of $P$. vinacea was the highest compared to $P$. chlamydocopiosa and $P$. pye. Paraphoma vinacea infected crown and upper root tissues of all the plants in the first experiment and basal petiole, crown and root tissues of $90 \%$ of the inoculated plants in the second experiment. Upper root and crown infection with $P$. chlamydocopiosa occurred in $60 \%$ of the inoculated plants in the first experiment and $50 \%$ in the second experiment. Paraphoma pye infected crown and upper root tissues of $60 \%$ of the plants in the first experiment and basal petiole, crown and upper root tissues of $70 \%$ in the second experiment. No Paraphoma isolates were recovered from leaves, nor from any tissues of plants inoculated with water in either experiment (Table 3). Crown discoloration of plants infected with $P$. chlamydocopiosa, $P$. pye and $P$. vinacea was also observed in the root dip inoculated plants.

Paraphoma chlamydocopiosa, $P$. pye and $P$. vinacea were able to significantly reduce above ground, below ground and total biomass of the root dip inoculated plants (Table 4).

Infection by all the Paraphoma species significantly reduced above ground, below ground and total biomass relative to the control; however, biomass values for each species were very similar and not significantly different from each other.

\section{Leaf and petiole inoculation}

Two weeks after spray inoculation of the plants in vivo with $P$. chlamydocopiosa and $P$. pye, necrotic leaf lesions developed on both sides of the leaves and petioles. However, lesions 
were small and did not coalesce. No leaf symptoms were observed on the plants inoculated with $P$. vinacea.

Paraphoma chlamydocopiosa caused reddish-brown and water-soaked, necrotic lesions mostly in the middle of the leaves (Fig. 4), while lesions produced by P. pye were yellowish to pale brown and caused margins of the leaf to curl (Fig. 5). However, results from the in vitro infection showed that all three species were able to cause lesions similar to those described for in vivo inoculation (Figs 4 \& 5). No symptoms were observed on the control plants in in vivo or in vitro experiments.

\section{Discussion}

Two new pathogenic species of Paraphoma, $P$. chlamydocopiosa and $P$. pye, were identified from phylogenetic studies and morphological characters, and their pathogenicity as leaf and crown rot pathogens was confirmed. The three-gene PHYML phylogenetic tree of ITS-EF1TUB separated P. chlamydocopiosa isolates into a well-supported monophyletic clade, and although $P$. pye clustered with $P$. vinacea there was significant bootstrap support and morphological differences to support a new species. Moreover, morphological differences were observed between $P$. chlamydocopiosa and $P$. pye isolates. Paraphoma chlamydocopiosa produced longer conidia than $P$. pye and $P$. vinacea. Red pigmentation of the colonies of $P$. chlamydocopiosa on OA, MEA and CHA was similar to $P$. vinacea but less intense and no red pigmentation was observed in the colonies of $P$. pye on any of the three different media. Paraphoma pye produced distinctive bilocular pycnidia, which did not occur in $P$. chlamydocopiosa or $P$. vinacea.

Pathogenicity of these species on pyrethrum was also confirmed in vivo and in vitro in pathogenicity trials. Above-, below-ground and total biomass were significantly reduced by $P$. chlamydocopiosa, $P$. pye and $P$. vinacea in both glasshouse root dip inoculation experiments. Pathogenicity of Paraphoma vinacea to pyrethrum was previously reported by Moslemi et al. (2016). Paraphoma chlamydocopiosa and $P$. pye also produced leaf lesions in glasshouse bioassays whereas $P$. vinacea did not. However, all three pathogens were able to cause leaf symptoms in inoculated detached leaves and petioles in vitro so may be regarded as both foliar and crown rot pathogens. It has been confirmed that $P$. vinacea is a severe crown and root rot pathogen of pyrethrum (Moslemi et al., 2016). Under favourable 
environmental conditions in the field, $P$. chlamydocopiosa and $P$. pye may be able to infect leaves of pyrethrum plants and cause foliar necrotic lesions, hence the reported isolation of $P$. pye or P. chlamydocopiosa (P. chrysanthemicola) in field surveys (Hay et al., 2015).

Aveskamp et al. (2008) reported that species of Phoma are dispersed easily by wind, water splash or birds. Therefore, it is probable that $P$. chlamydocopiosa and $P$. pye can be readily spread long distances through the fields in Tasmania under high rainfall. Therefore, each treatment was separately allocated to each group of 10 plants in the root dip inoculation experiments to avoid cross-contamination and spread of the spores via water splash in the glasshouse. Experiments were independently repeated to achieve true replication. This permitted an estimation of the variability within a treatment and the statistical inference. In addition, inoculated but noninfected plants were excluded from the analyses to reduce the measurement error.

In Hay et al. (2015), P. chlamydocopiosa was misidentified as P. chrysanthemicola and thus it is unlikely that $P$. chrysanthemicola exists in pyrethrum fields in Australia. This has important biosecurity implications for the introduction of Chrysanthemum or other hosts into Australia that may be infected with P. chrysanthemicola, as it has been reported on Chrysanthemum morifolium, but its pathogenicity is unknown on pyrethrum. Hay et al. (2015) reported tow frequency of isolation $(<7.7 \%)$ of $P$. chlamydocopiosa or $P$. pye (P. chrysanthemicola) from the leaf lesions in northern Tasmania in 2012. However, these pathogens were prevalent in 26\% and $48 \%$ of commercial fields surveyed in spring 2012 and 2013, respectively, suggesting that either or both of these pathogen(s) are relatively widespread throughout the cropping region (Hay et al., 2015). Further research needs to be carried out in order to determine the extent of infection of pyrethrum plants by $P$. chlamydocopiosa and $P$. pye in the fields.

Most previously recognised species of Paraphoma are soilborne and cause root and crown diseases (Boerema et al., 2004; Moslemi et al., 2016) except for P. dioscoreae, which was first isolated from the leaves of Dioscorea tokoro in South Korea in 2003 (Quaedvlieg et al., 2013). Paraphoma chrysanthemicola has been shown to cause root and basal stem rot in North America and western Europe, and may cause damping-off of seedlings. It is known as the cause of stunted roots of black salsify (Scorzonera hispanica), and various Asteraceae in Belgium (De Gruyter et al., 2010). Species of $P$. radicina have been reported as saprophytes on root surfaces of monocotyledonous plants (Gramineae, Amaryllidaceae, Iridaceae, 
Liliaceae, Orchidaceae and Zingiberaceae) in Australia, Eurasia and North and South America; and in soil and on animal and inorganic substrates (De Gruyter et al., 2010). Paraphoma vinacea was also recovered from necrotic crown and root tissues of pyrethrum in northern Tasmania (Moslemi et al., 2016). Paraphoma fimeti has a broad host range on various plant families and has been isolated from diverse substrates.

In conclusion, Paraphoma chlamydocopiosa and $P$. pye were described as two new pathogens of pyrethrum, causing necrotic leaf lesions and crown rot of pyrethrum plants. However, the role of these pathogens as foliar or crown rot pathogens associated with yield decline in the fields of northern Tasmania needs to be further assessed.

\section{Acknowledgements}

The authors would like to thank Botanical Resources Australia - Agricultural Services Pty Ltd for providing pyrethrum seedlings and supplementary funding for this project. Thanks also to the University of Melbourne for Melbourne International Research Scholarship (MIRS) and Melbourne International Fee Remission Scholarship (MIFRS), which supported A.M. during this study.

\section{References}

Aveskamp MM, De Gruyster J, Crous PW, 2008. Biology and recent developments in the systematics of Phoma, a complex genus of major quarantine significance. Fungal Diversity 31, 1-18.

Aveskamp MM, De Gruyter J, Woudenberg JH, Verkley GJ, Crous PW, 2010. Highlights of the Didymellaceae: A polyphasic approach to characterise Phoma and related pleosporalean genera. Studies in Mycology 65, 1-60.

Barimani M, Pethybridge SJ, Vaghefi N, Hay FS, Taylor PWJ, 2013. A new anthracnose disease of pyrethrum caused by Colletotrichum tanaceti sp. nov. Plant Pathology 62, $1248-57$.

Bhuiyan MB, Groom T, Nicolas ME, Taylor PWJ, 2017. Infection process of 
Stagonosporopsis tanaceti in pyrethrum seed and seedlings. Plant Pathology 66. Doi: 10.1111/ppa.12622.

Boerema GH, De Gruyter J, Noordeloos ME, Hamers MEC, 2004. Phoma Identification Manual: Differentiation of Specific and Infra-Specific Taxa in Culture. Wallingford, UK: CABI Publishing.

Chen Q, Jiang JR, Zhang GZ, Cai L, Crous PW, 2015. Resolving the Phoma enigma. Studies in Mycology 82, 137-217.

Crous PW, Gams W, Stalpers JA, Robert V, Stegehuis G., 2004. MycoBank: an online initiative to launch mycology into the 21st century. Studies in Mycology 50, 19-22.

Crous PW, Verkley GJM, Groenewald JZ, Samson RA, 2009. Fungal Biodiversity. CBS Laboratory Manual Series 1. Utrecht, Netherlands: CBS-KNAW Fungal Biodiversity Centre.

De Gruyter, Woudenberg JH, Aveskamp MM, Verkley GJ, Groenewald JZ, Crous PW, 2010. Systematic reappraisal of species in Phoma section Paraphoma, Pyrenochaeta and Pleurophoma. Mycologia 102, 1066-81.

De Gruyter, Woudenberg JHC, Aveskamp MM, Verkley GJM, Groenewald JZ, Crous PW, 2013. Redisposition of phoma-like anamorphs in Pleosporales re-evaluation. Studies in Mycology 75, 1-36.

Dorenbosch MJ, 1970. Key to nine ubiquitous soil-borne phoma-like fungi. Persoonia 6, 114.

Ge X, Zhou R, Yuan Y, Xu H, Fu H, Li H, 2016. Identification and characterization of Paraphoma chrysanthemicola causing leaf spot disease on Atractylodes japonica in China. Journal of Phytopathology 164, 372-7.

Grdisa M, Carovic-Stanko K, Kolak I, Satovic Z, 2009. Morphological and biochemical diversity of dalmatian pyrethrum (Tanacetum cinerariifolium (Trevir.) Sch.Bip.). Agriculturae Conspectus Scientificus 74, 73-80.

Guindon S, Gascuel O, 2003. A simple, fast, and accurate algorithm to estimate large phylogenies by maximum likelihood. Systematic Biology 52, 696-704. 
Hay FS, Gent DH, Pilkington S, Pearce TL, Scott JB, Pethybridge SJ, 2015. Changes in distribution and frequency of fungi associated with foliar diseases complex of pyrethrum in Australia. Plant Disease 9, 1227-35.

Johnston PR, 1981. Phoma on New Zealand grasses and pasture legumes. New Zealand Journal of Botany 19, 173-86.

Kearse M, Moir R, Wilson A et al., 2012. GENEIOUs basic: an integrated and extendable desktop software platform for the organization and analysis of sequence data. Bioinformatics 28, 1647-9.

Moslemi A, Ades P, Groom T, Crous PW, Nicolas ME, Taylor PWJ, 2016. Paraphoma crown rot of pyrethrum (Tanacetum cinerariifolium). Plant Disease 100, 2363-9.

Moslemi A, Ades PK, Groom T, Nicolas ME, Taylor PWJ, 2017. Fusarium oxysporum and Fusarium avenaceum associated with yield-decline of pyrethrum in Australia. European Journal of Plant Pathology. Doi: 10.1007/s10658-017-1161-5.

O’Malley TB, Hay FS, Scott JB, Gent DH, Shivas RG, Pethybridge SJ, 2015. Carpogenic germination of sclerotia of Sclerotinia minor and ascosporic infection of pyrethrum flowers. Canadian Journal of Plant Pathology 37, 179-87.

Pearce TL, Scott JB, Crous PW, Pethybridge SJ, Hay FS, 2015. Tan spot of pyrethrum is caused by a Didymella species complex. Plant Pathology 65, 1170-84.

Pethybridge SJ, Jones SJ, Shivas RG, Hay FS, Wilson CR, Groom T, 2008. Tan spot: a new disease of pyrethrum caused by Microsphaeropsis tanaceti sp. nov. Plant Pathology 57, $1058-65$.

Quaedvlieg W, Verkley GJM, Shin HD et al., 2013. Sizing up Septoria. Studies in Mycology 75, 307-90.

Rayner RW, 1970. A Mycological Colour Chart. Kew, UK: Commonwealth Mycological Institute.

Srivastava SNS, 1953. On the occurrence of Phoma chrysanthemicola Hollos on Chrysanthemum sp. Current Sciences Journal 22, 216. 
Swofford DL, 2003. PAUP*. Phylogenetic Analysis Using Parsimony (*and Other Methods). Version 4. Sunderland, MA, USA: Sinauer Associates.

Tamura K, Stecher G, Peterson D, Filipski A, Kumar S, 2013. MEGA 6: molecular evolutionary genetics analysis Version 6.0. Molecular Biology and Evolution 30, 27257.

Vaghefi N, Hay FS, Pethybridge SJ, Ford R, Taylor PWJ, 2016. Development of a multiplex PCR diagnostic assay for the detection of Stagonosporopsis species associated with ray blight of Asteraceae. European Journal of Plant Pathology 146, 581-95.

de Vienne DM, Giraud T, Martin OC, 2007. A congruence index for testing topological similarity between trees. Bioinformatics 23, 3119-24.

\section{Figure legends}

Figure 1 Maximum likelihood PHYML combined phylogenetic tree inferred from internal transcribed spacer (ITS), translation elongation factor 1- $\alpha(E F 1-\alpha)$ and $\beta$-tubulin (TUB). Highest $\log$ likelihood -2871.0461 . The analysis involved 31 nucleotide sequences of Paraphoma isolates described in this study and reference isolates obtained from GenBank. The neighbour joining bootstrap value is shown on the left only where it differs from the PHYML support value. Bootstrap values of $75 \%$ or greater are shown. Scale bar indicates expected changes per site. Host column refers to the original host where the pathogens were first isolated.

Figure 2 Paraphoma chlamydocopiosa (BRIP 65168) (a), (b) and (c) colony morphology and pigmentation on OA, MEA and CHA, respectively; (d) globose pycnidia on PDA; (e) pycnidial cell wall; (f ) conidiogenous cells on PDA; (g) ellipsoid and oblong conidia on PDA; (h) micropycnidia on OA; (i) chains of chlamydospores on CHA. Scale bars (d) 200 $\mu \mathrm{m}$, (e) $20 \mu \mathrm{m}$, (f) $5 \mu \mathrm{m}$, (g) and (i) $10 \mu \mathrm{m}$, (h) $100 \mu \mathrm{m}$.

Figure 3 Papraphoma pye (BRIP 65169) (a), (b) and (c) colony morphology and pigmentation on OA, MEA and CHA, respectively; (d) bilocular pycnidium on OA; (e) unilocular pycnidium on OA; (f), (g) and (h) cross sections of a pycnidium ( $6 \mu \mathrm{m}$ thickness); (i) oblong and ellipsoid conidia on OA; (j) sclerotioid chlamydospores on OA; (k) 
chlamydospores in chain. (l)-(m) Conidiogenous cells on OA. Scale bars (d,e) $200 \mu \mathrm{m},(\mathrm{f}, \mathrm{g})$ $100 \mu \mathrm{m},(\mathrm{h}, \mathrm{i}) 10 \mu \mathrm{m},(\mathrm{j}, \mathrm{k}) 20 \mu \mathrm{m},(1, \mathrm{~m}) 5 \mu \mathrm{m}$.

Figure 4 Symptoms caused by Paraphoma chlamydocopiosa (BRIP 65168) in in vivo and in vitro experiments; (a)-(c) necrotic lesions caused by $P$. chlamydocopiosa on detached leaves and petioles in vitro, 8 days after inoculation; (d) a transverse section of crown tissues showing discolouration caused by P. chlamydocopiosa, 2 months after root dip inoculation; (e) reddish-brown necrotic leaf lesion on both sides of the leaves, 2 weeks after spray inoculation of the leaves in vivo.

Figure 5 Symptoms caused by Paraphoma pye (BRIP 65169) in in vivo and in vitro experiments. (a)-(b) Dark brown to black necrotic lesions caused by $P$. pye on detached leaves and petioles in vitro, 8 days after inoculation; (c) marginal chlorosis of the leaves, 2 weeks after spray inoculation in vivo; (d) necrosis of the newly grown petioles in vivo, 2 weeks after spray inoculation.

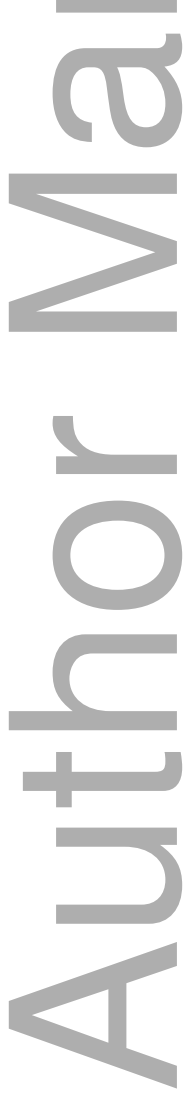


Table 1 Information of the location in Tasmania (Australia), field code, collectors and dates in which new Paraphoma isolates from pyrethrum (Tanacetum cinerariifolium) used in this study were recovered

\begin{tabular}{llllll}
\hline Acc. number & Species & Date isolated & Collector & Field code & Region \\
\hline BRIP 57988 & P. chlamydocopiosa & $2012-08-06$ & T. Pearce & 70042 & Table Cape \\
BRIP 65178 & P. chlamydocopiosa & $2012-08-14$ & T. Pearce & 70042 & Table Cape \\
BRIP 57989 & P. chlamydocopiosa & $2012-08-21$ & T. Pearce & 51907 & East Devonport \\
BRIP 65177 & P. chlamydocopiosa & $2012-08-27$ & T. Pearce & 70046 & Table Cape \\
BRIP 65173 & P. chlamydocopiosa & $2012-08-27$ & T. Pearce & 57348 & Wesley Vale \\
BRIP 65176 & P. chlamydocopiosa & $2013-07$ & F. Hay & 48303 & North Motton \\
BRIP 65179 & P. chlamydocopiosa & $2014-07-21$ & J. Scott & 82205 & Circular Head \\
BRIP 65174 & P. chlamydocopiosa & $2014-09-23$ & J. Scott & 87402 & Wynyard \\
BRIP 65168 & P. chlamydocopiosa & 2013 & N. Vaghefi & 70047 & Table Cape \\
BRIP 65170 & P. chlamydocopiosa & 2013 & N. Vaghefi & 70047 & Table Cape \\
BRIP 65169 & P. pye & 2013 & N. Vaghefi & 70047 & Table Cape \\
BRIP 65171 & P. pye & 2013 & N. Vaghefi & 70047 & Table Cape \\
BRIP 63682 & P. vinacea & $2014-06$ & A. Moslemi & 64209,49206 & Devonport \\
BRIP 63683 & P. vinacea & $2014-07$ & A. Moslemi & 49207,74201 & Devonport \\
BRIP 63684 & P. vinacea & $2014-08$ & A. Moslemi & 47110,46410 & Devonport \\
BRIP 63685 & P. vinacea & $2014-09$ & A. Moslemi & 86901 & Devonport \\
\hline & & & & & \\
\hline
\end{tabular}


Table 2 Collection details and GenBank accession numbers of isolates

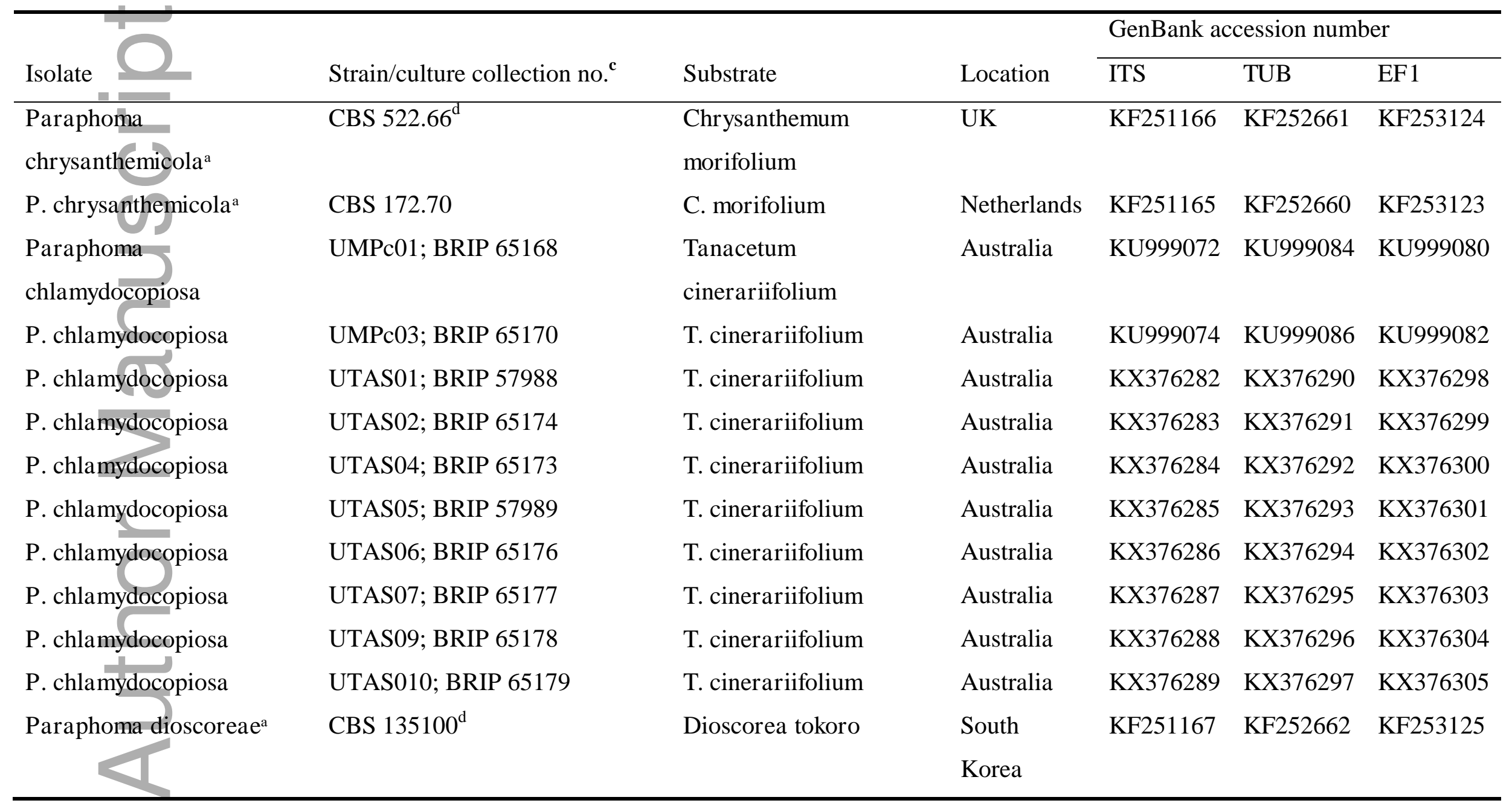

This article is protected by copyright. All rights reserved 


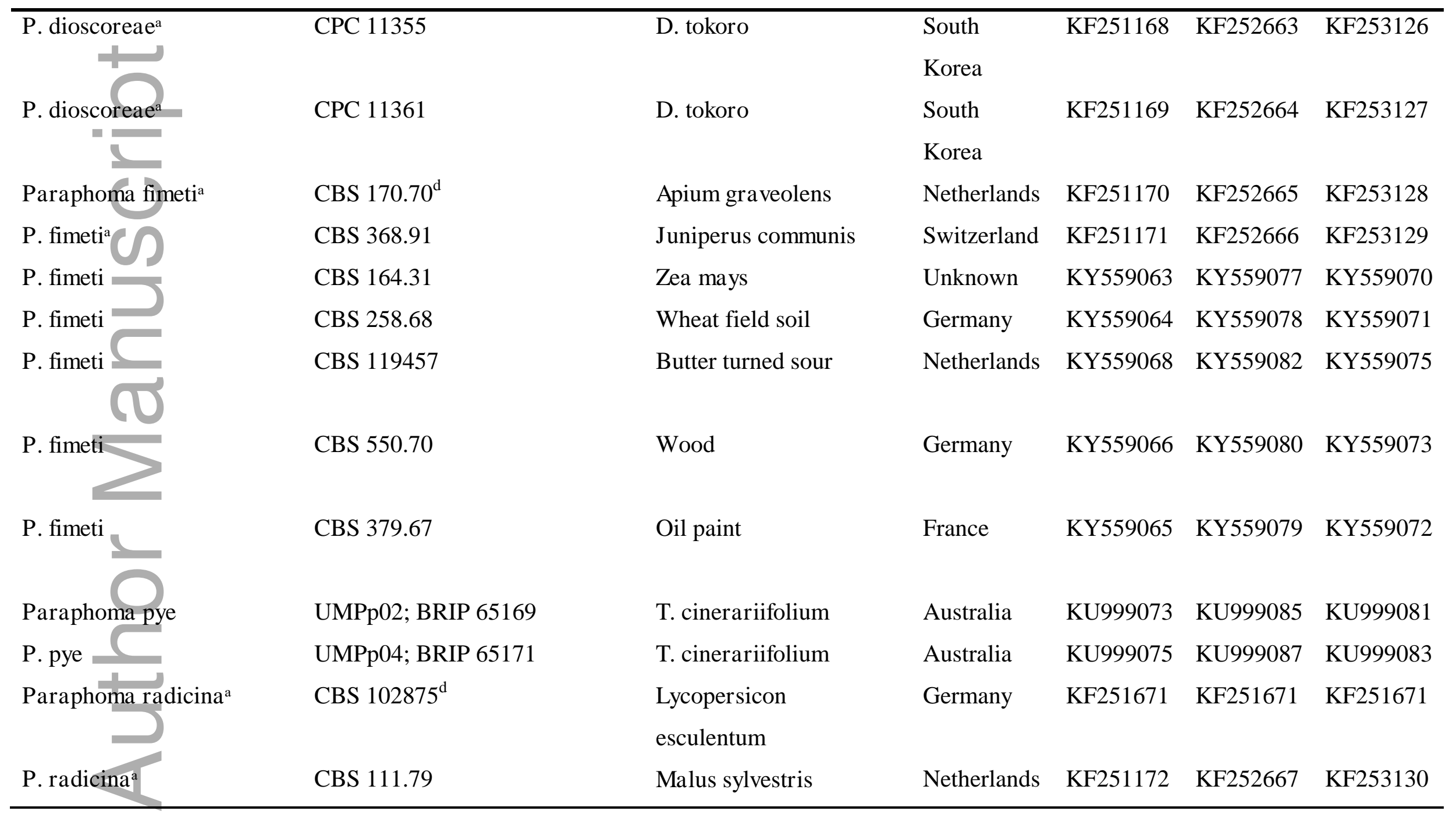

This article is protected by copyright. All rights reserved 


\begin{tabular}{|c|c|c|c|c|c|c|}
\hline Paraphoma vinacea $^{\mathrm{b}}$ & $\begin{array}{l}\text { UMPv001; BRIP 63684; CBS } \\
\text { 141995 }^{\text {d }}\end{array}$ & T. cinerariifolium & Australia & KU176884 & KU176892 & KU176896 \\
\hline P. vinacea & UMPv002; BRIP 63683 & T. cinerariifolium & Australia & KU176885 & KU176893 & KU176897 \\
\hline P. vinace ${ }^{b}$ & UMPv004; BRIP 63685 & T. cinerariifolium & Australia & KU176887 & KU176895 & KU176899 \\
\hline Neosetophoma samaroruma & CBS 138.96 & Phlox paniculata & Netherlands & KF251160 & KF252655 & KF253119 \\
\hline
\end{tabular}

${ }^{\mathrm{a}}$ Quaedvlieg et al. (2013).

${ }^{\mathrm{b}}$ Moslemi et al. (2016).

${ }^{c}$ BRIP, Queensland Plant Pathology herbarium, Brisbane, Australia; CBS, Westerdijk Fungal Biodiversity Institute, Netherlands; CPC, Culture collection of Pedro Crous, housed at the Westerdijk Institute, Netherlands; UMPc, University of Melbourne, Paraphoma chlamydocopiosa strain; UMPp, University of Melbourne, Paraphoma pye strain; UTAS, University of Tasmania.

${ }^{\mathrm{d}}$ CBS 522.66 is the ex-neotype of P. chrysanthemicola Hollos; CBS 135100 is the ex-holotype of P. dioscoreae; CBS 170.70 is the ex-neotype of P. fimeti Branaud; CBS 102875 is the ex-epitype of P. radicina (McAlpine) Morgan-Jones and J. F. White; CBS 141995 is the ex-holotype of P. vinacea Moslemi and Taylor.

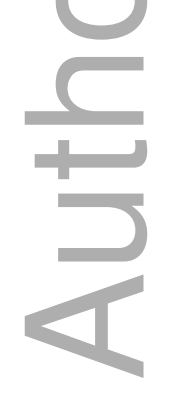

This article is protected by copyright. All rights reserved 
Table 3 Disease incidence and tissues of pyrethrum plants infected 2 months after inoculation with Paraphoma chlamydocopiosa, $\mathrm{P}$. pye and P. vinacea

\begin{tabular}{|c|c|c|c|c|c|c|c|}
\hline \multirow{2}{*}{\multicolumn{2}{|c|}{ 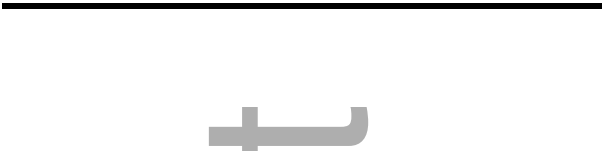 }} & \multirow{3}{*}{$\begin{array}{l}\text { No. of } \\
\text { replicate } \\
\text { plants }\end{array}$} & \multirow{3}{*}{$\begin{array}{l}\text { No. of } \\
\text { infected } \\
\text { plants }^{\mathrm{a}}\end{array}$} & \multicolumn{4}{|c|}{ Incidence (\%) } \\
\hline & & & & & Basal & & \\
\hline Experiment & t Inoculum & & & Leaf & petiole & Crown & Root \\
\hline \multirow[t]{4}{*}{1} & Control & 10 & 0 & 0 & 0 & 0 & 0 \\
\hline & P. chlamydocopiosa & 10 & 6 & 0 & 0 & 10 & 50 \\
\hline & P. pye & 10 & 6 & 0 & 0 & 10 & 50 \\
\hline & P. vinacea & 10 & 10 & 0 & 0 & 50 & 80 \\
\hline \multirow[t]{4}{*}{2} & Control & 10 & 0 & 0 & 0 & 0 & 0 \\
\hline & P. chlamydocopiosa & 10 & 5 & 0 & 0 & 30 & 20 \\
\hline & P. pye & 10 & 7 & 0 & 40 & 40 & 0 \\
\hline & $P$. vinacea & 10 & 9 & 0 & 40 & 60 & 40 \\
\hline
\end{tabular}

${ }^{\mathrm{a}}$ Total number of plants from which the target pathogen was recovered.

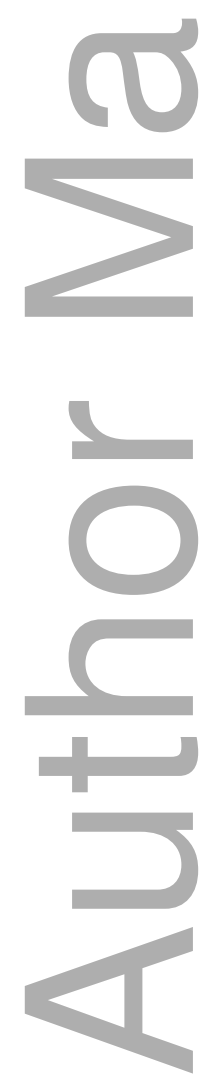

This article is protected by copyright. All rights reserved 
Table 4 Dry weights of the above and below ground portions of pyrethrum plants 2 months after inoculation with Paraphoma chlamydocopiosa, P. pye and P. vinacea

\begin{tabular}{llll}
\hline & \multicolumn{3}{l}{ Dry weight component $(\mathrm{g})$} \\
\cline { 2 - 4 } Treatment & Above ground & Below ground & Total \\
\hline Control & $7.10 \mathrm{a}$ & $4.52 \mathrm{a}$ & $11.50 \mathrm{a}$ \\
\hline P. chlamydocopiosa & $5.31 \mathrm{~b}$ & $2.85 \mathrm{~b}$ & $8.29 \mathrm{~b}$ \\
\hline P. pye & $5.21 \mathrm{~b}$ & $3.11 \mathrm{~b}$ & $8.39 \mathrm{~b}$ \\
P. vinacea & $5.73 \mathrm{~b}$ & $3.18 \mathrm{~b}$ & $8.91 \mathrm{~b}$ \\
\hline F $_{3,58}$ & 3.73 & 12.82 & 7.54 \\
P-value & $<0.01$ & $<0.001$ & $<0.0002$ \\
\hline
\end{tabular}

Means with different letters in the same column are significantly different by pairwise t-tests ( $\alpha$ $=0.05)$. In all cases the $F$ ratio for testing the treatment effect has 3 and $58 \mathrm{df}$. This was obtained by combining the two experiments and fitting a linear mixed model with different error terms in each experiment.

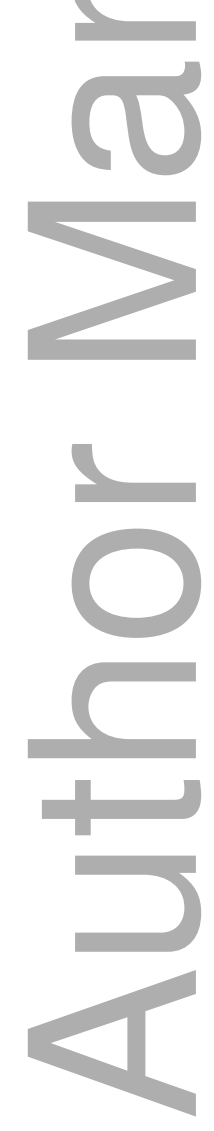




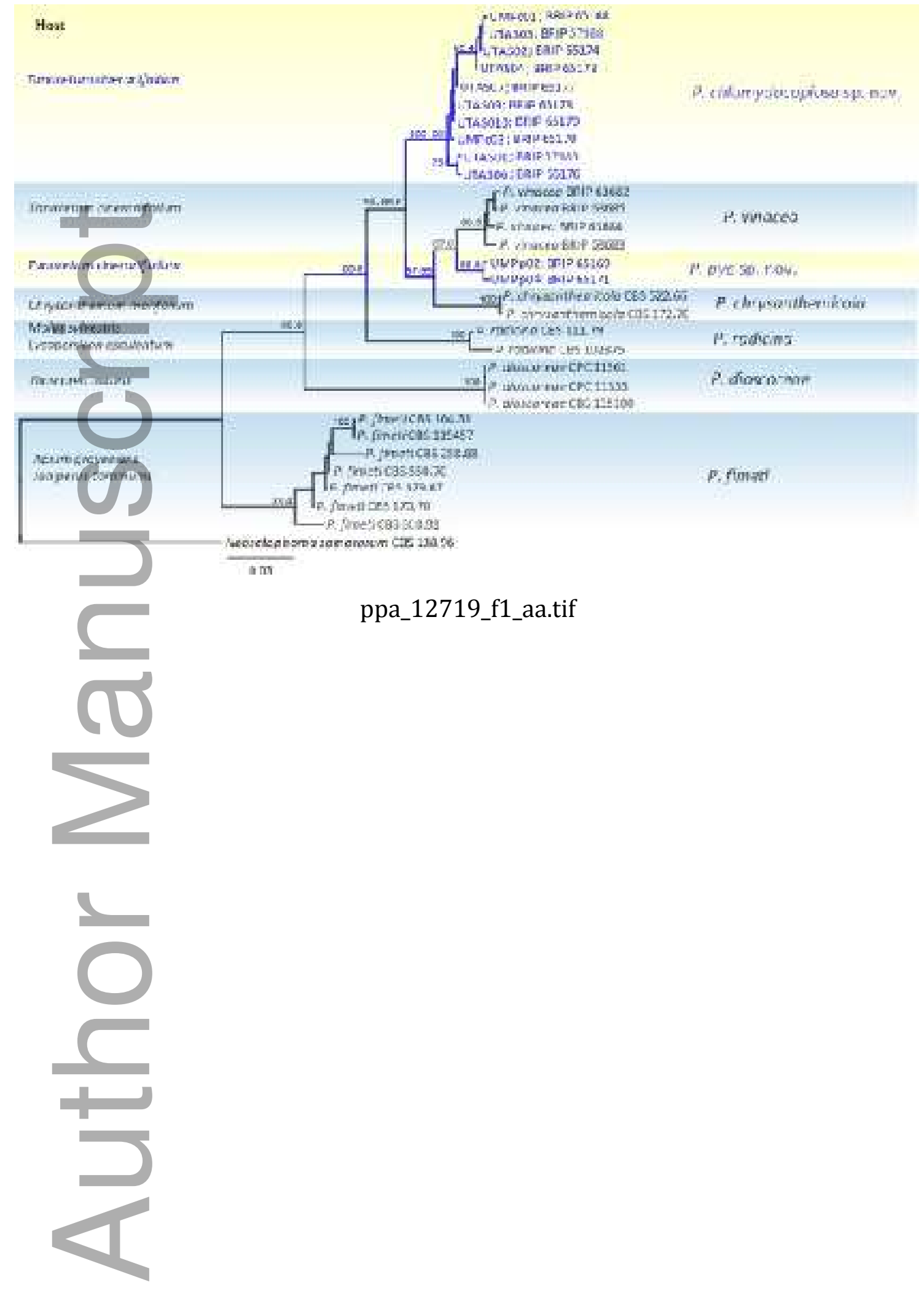

This article is protected by copyright. All rights reserved 

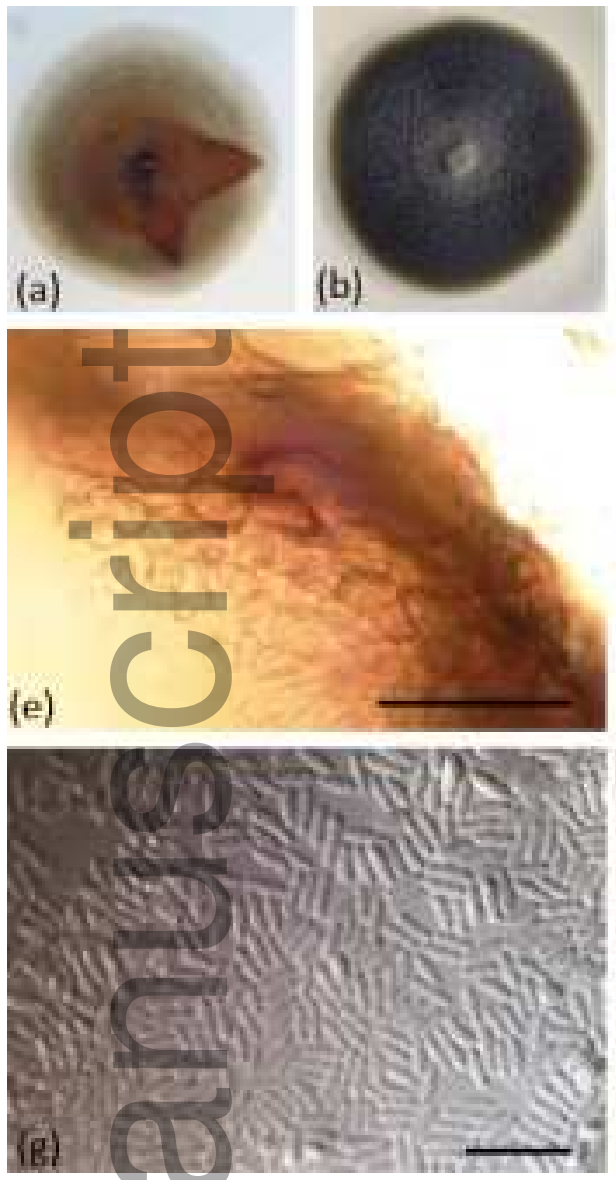

(B)
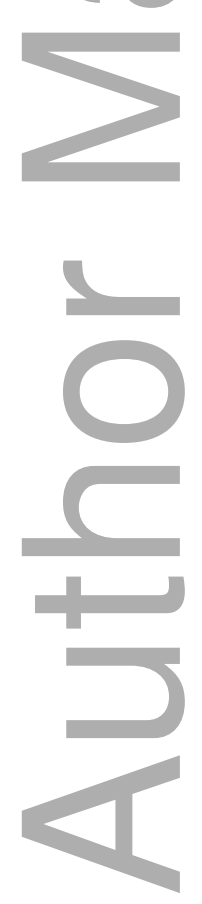
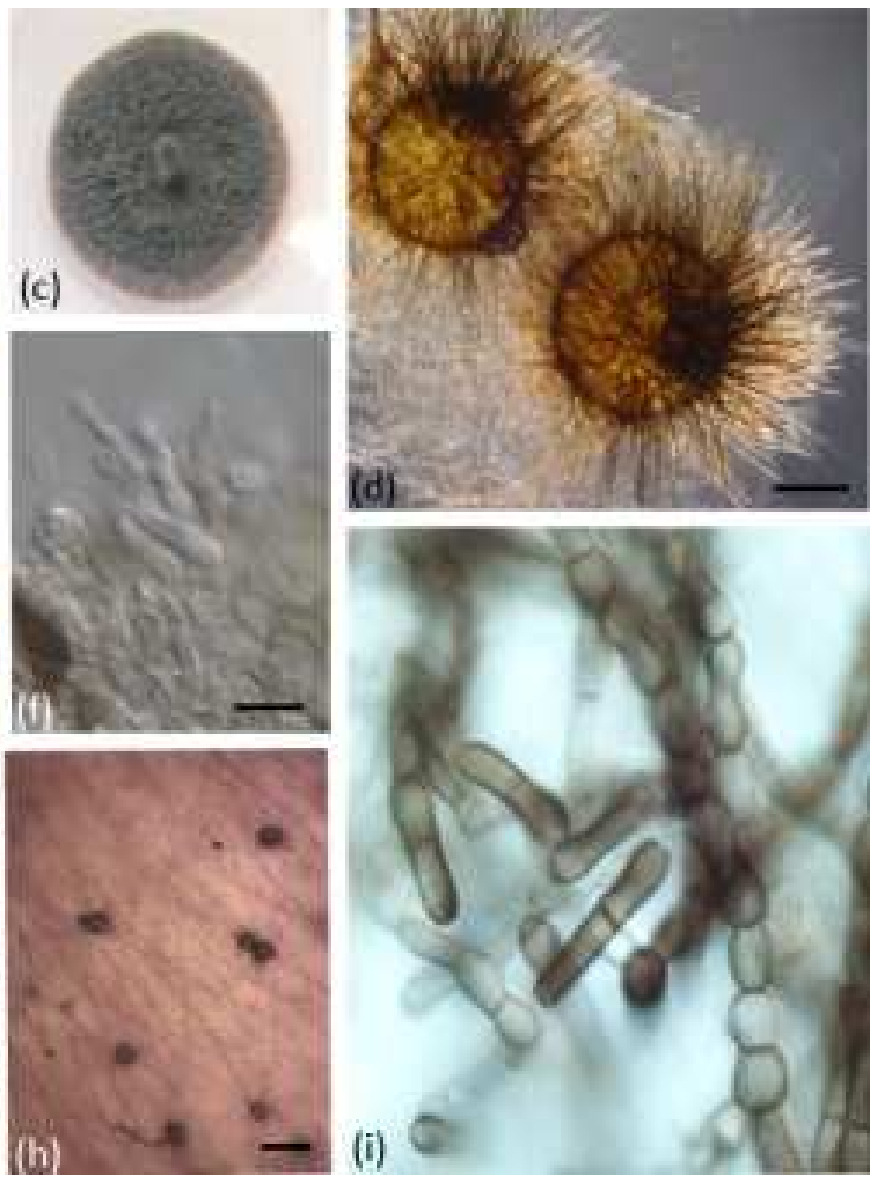

ppa_12719_f2_aa.tif 

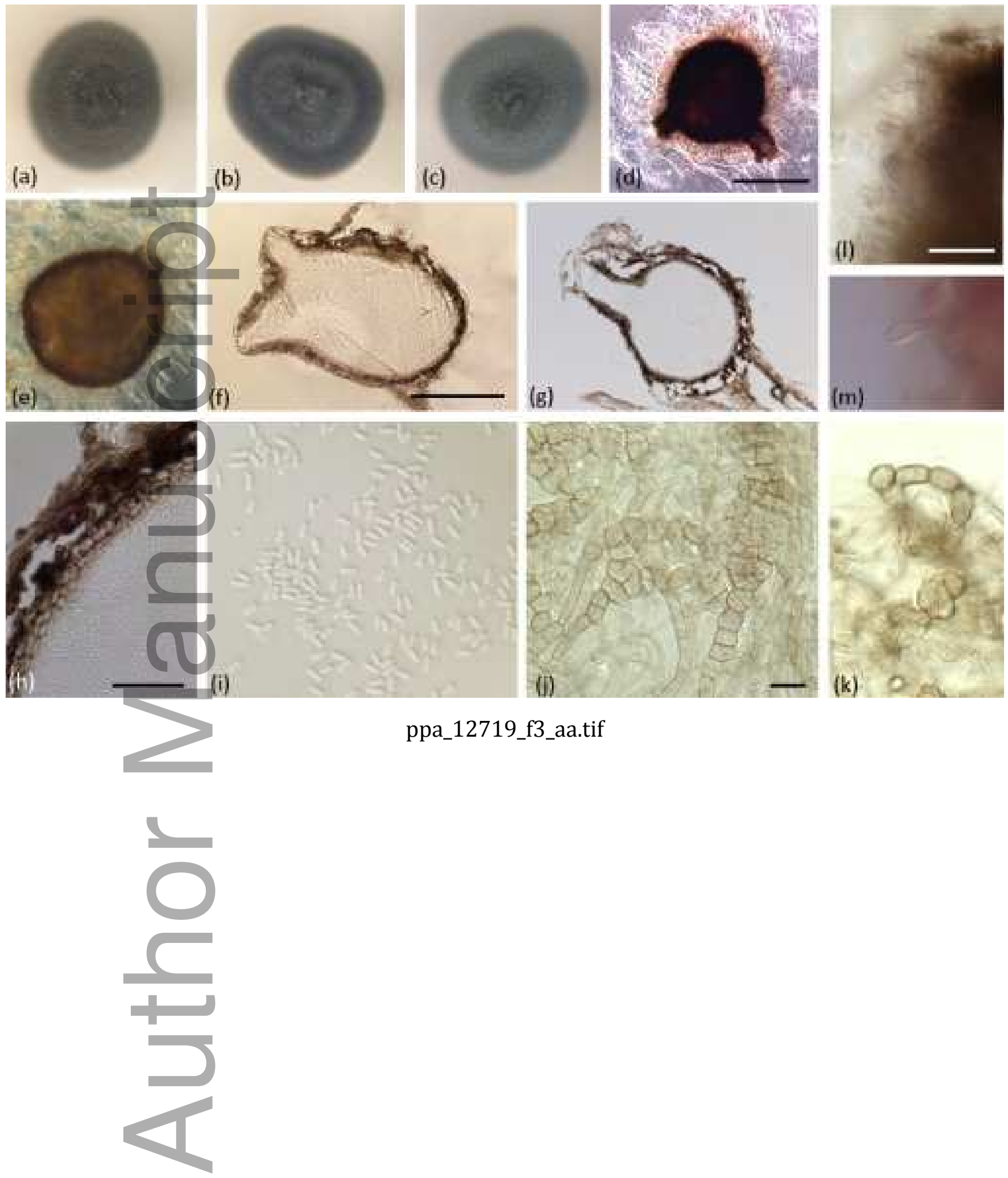


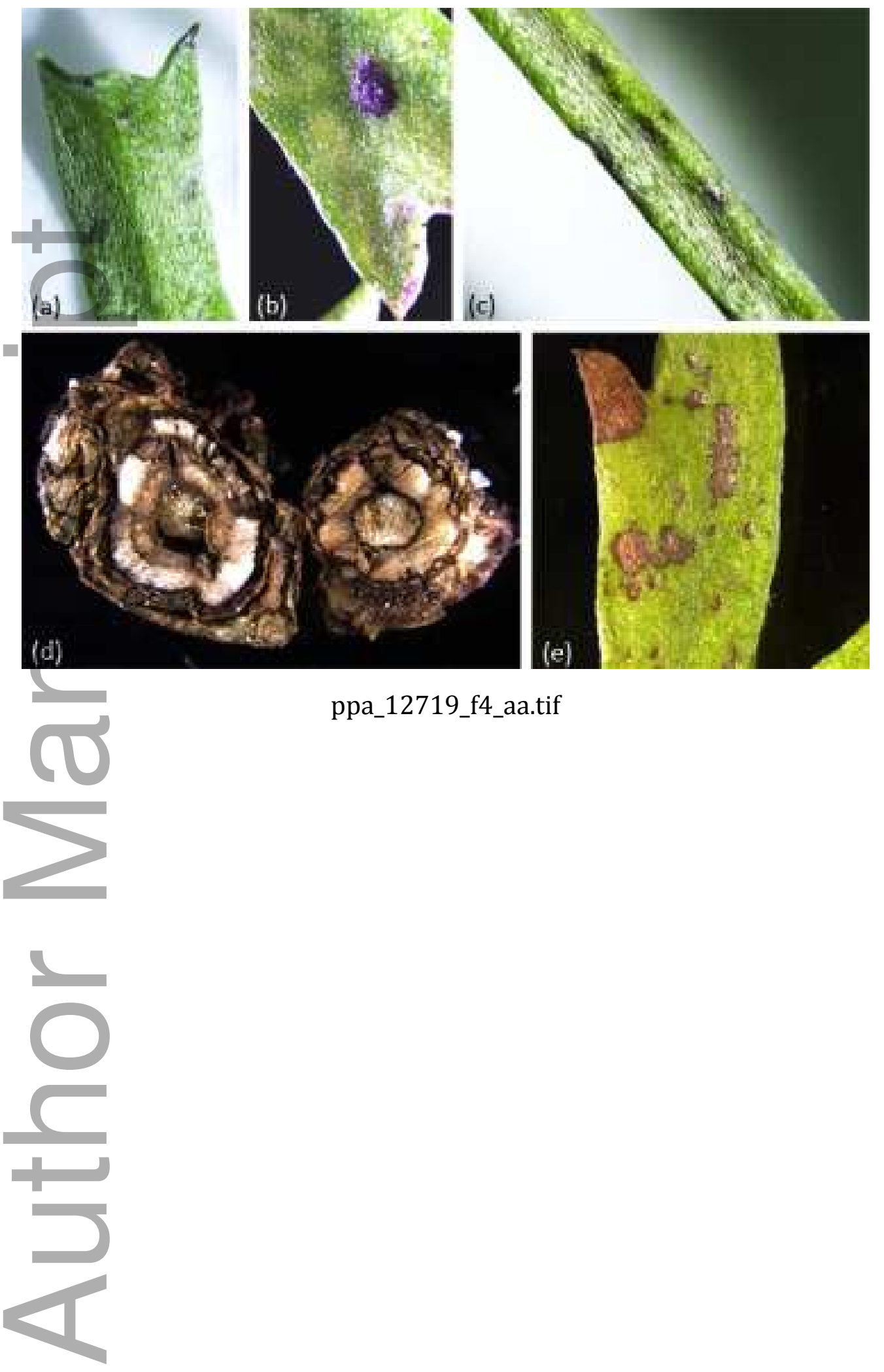

This article is protected by copyright. All rights reserved 

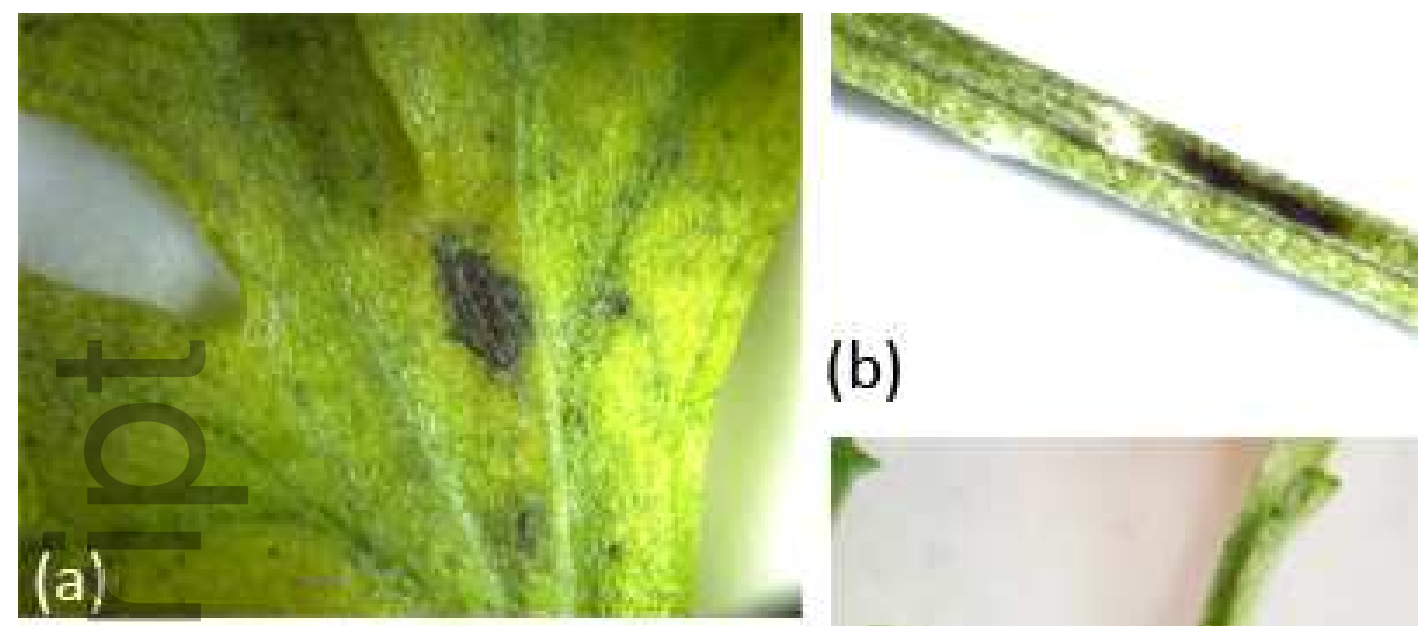

(b)
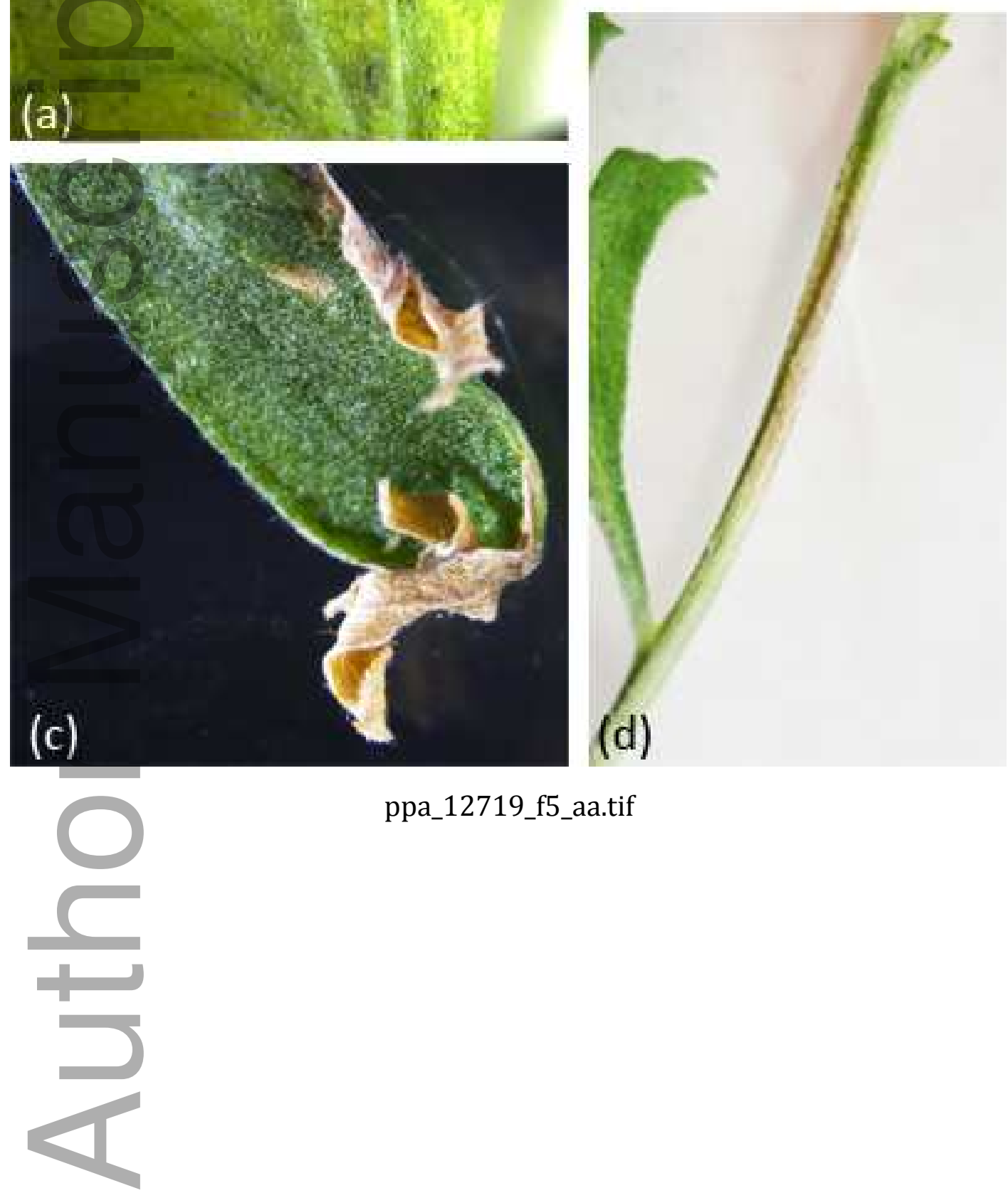

ppa_12719_f5_aa.tif 


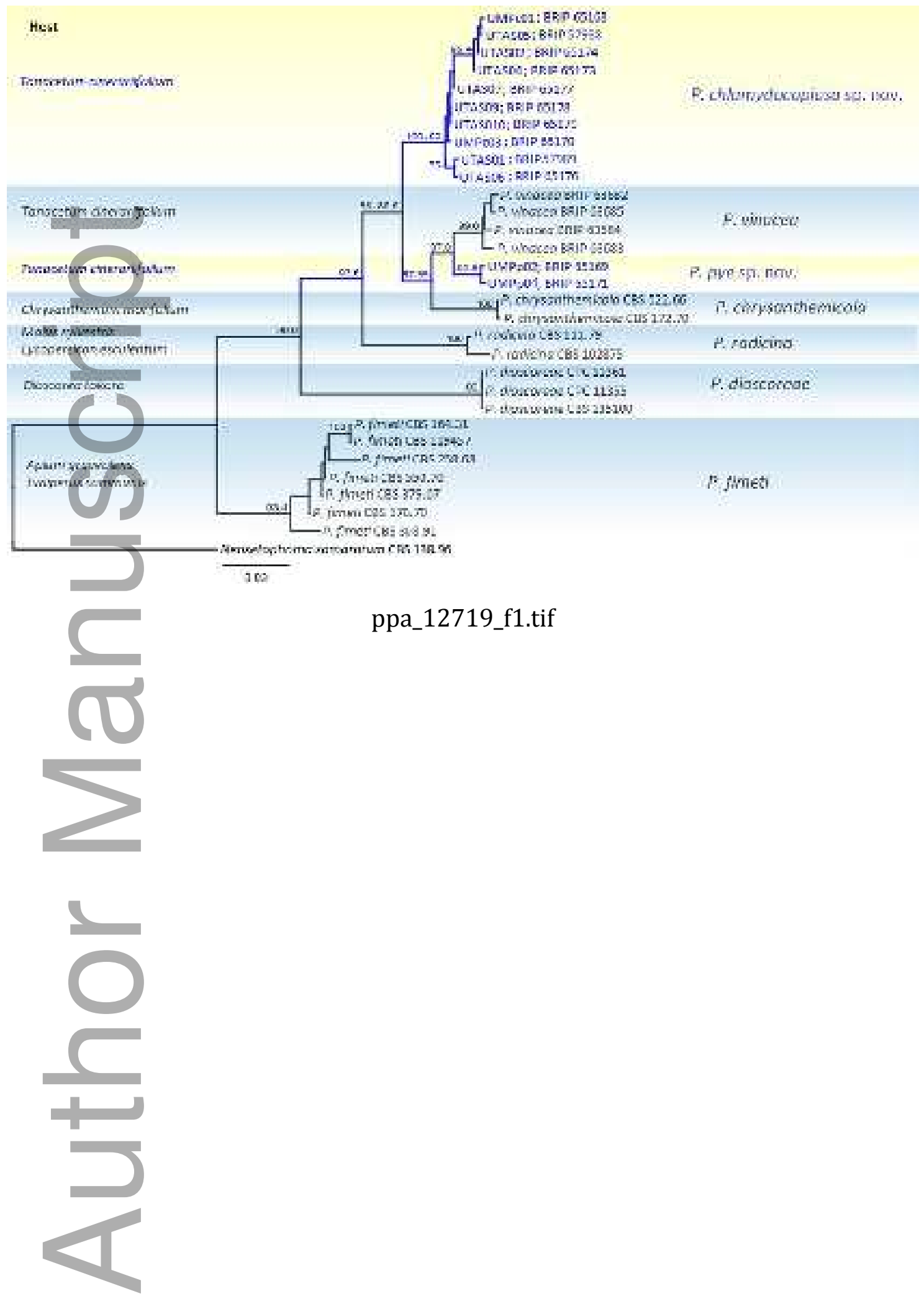

This article is protected by copyright. All rights reserved 

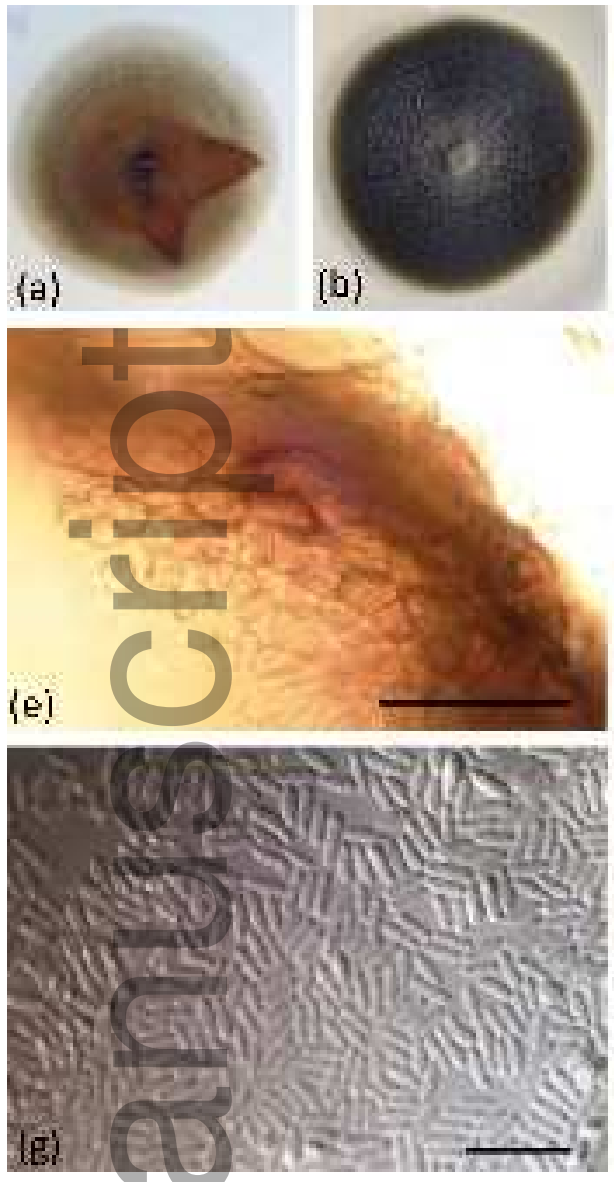

Le

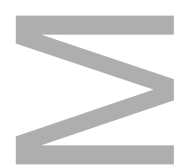

ppa_12719_f2.tif
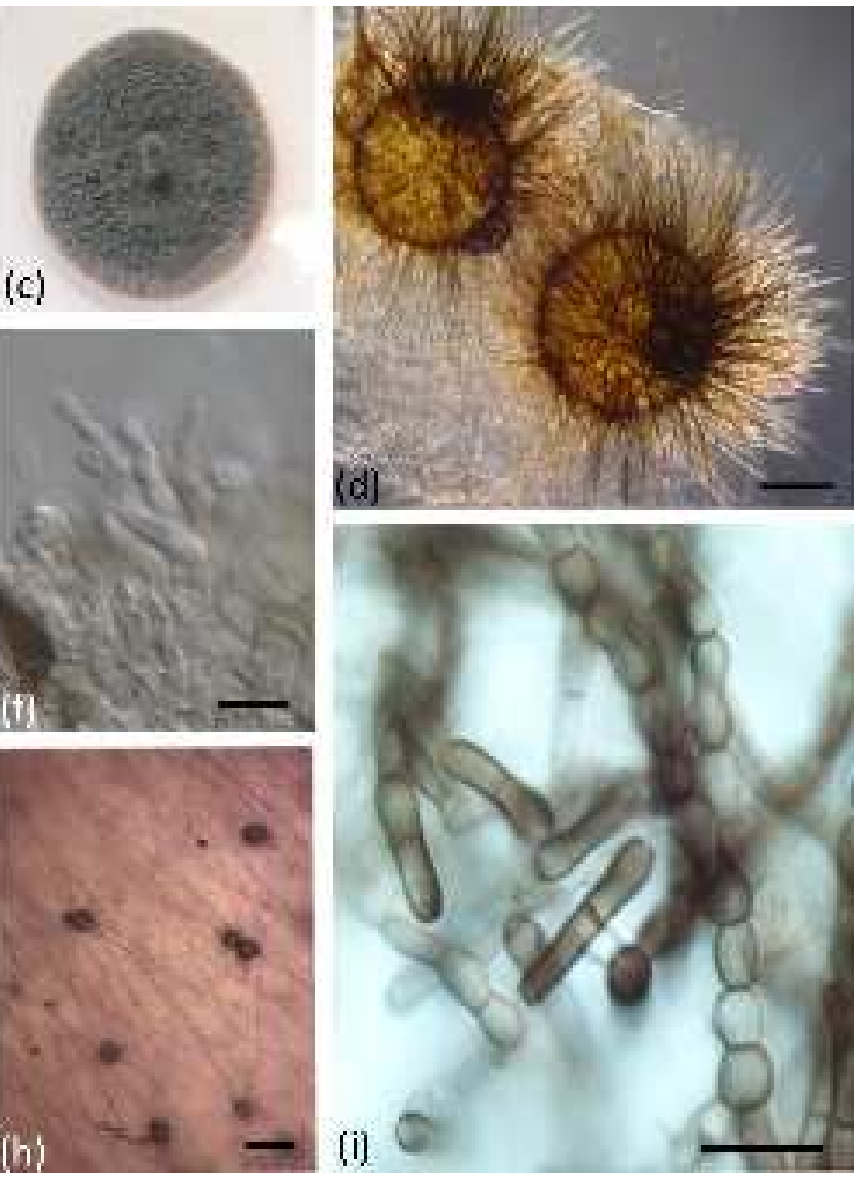

(i)
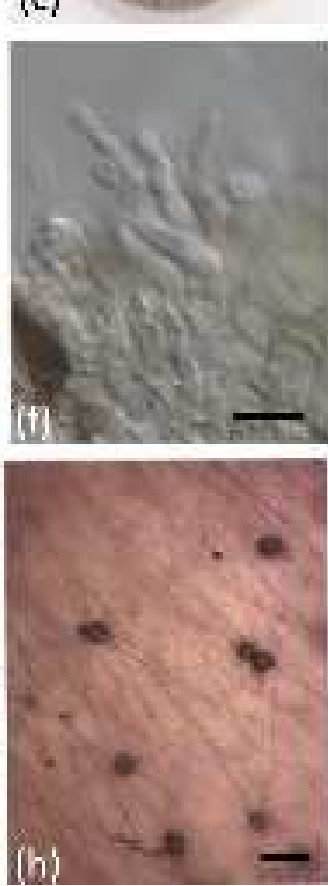

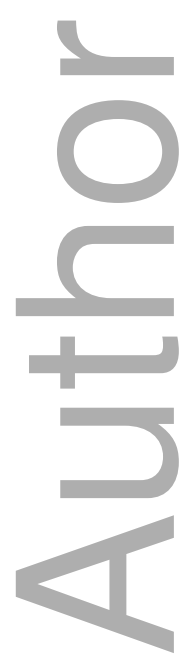



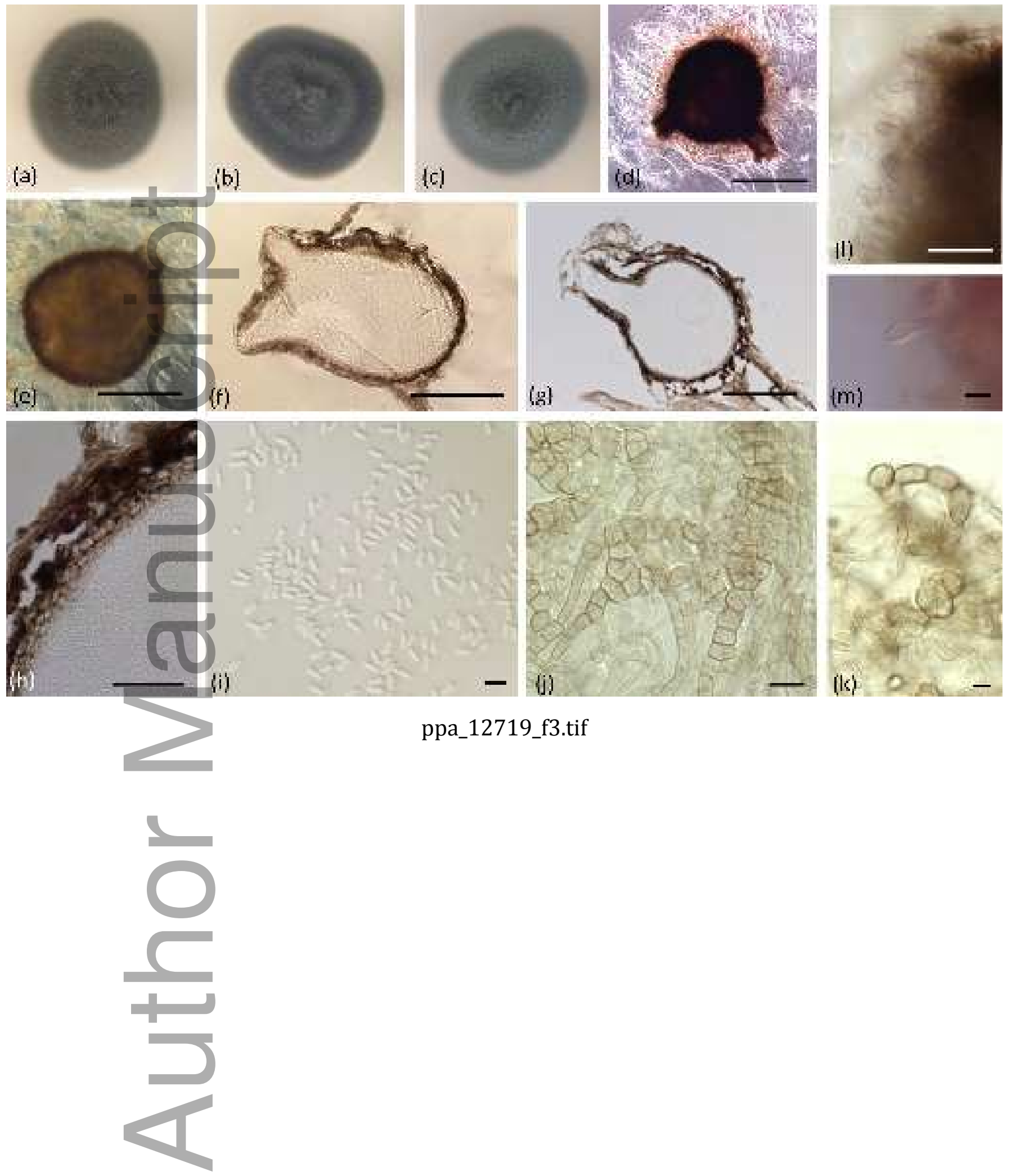

This article is protected by copyright. All rights reserved 

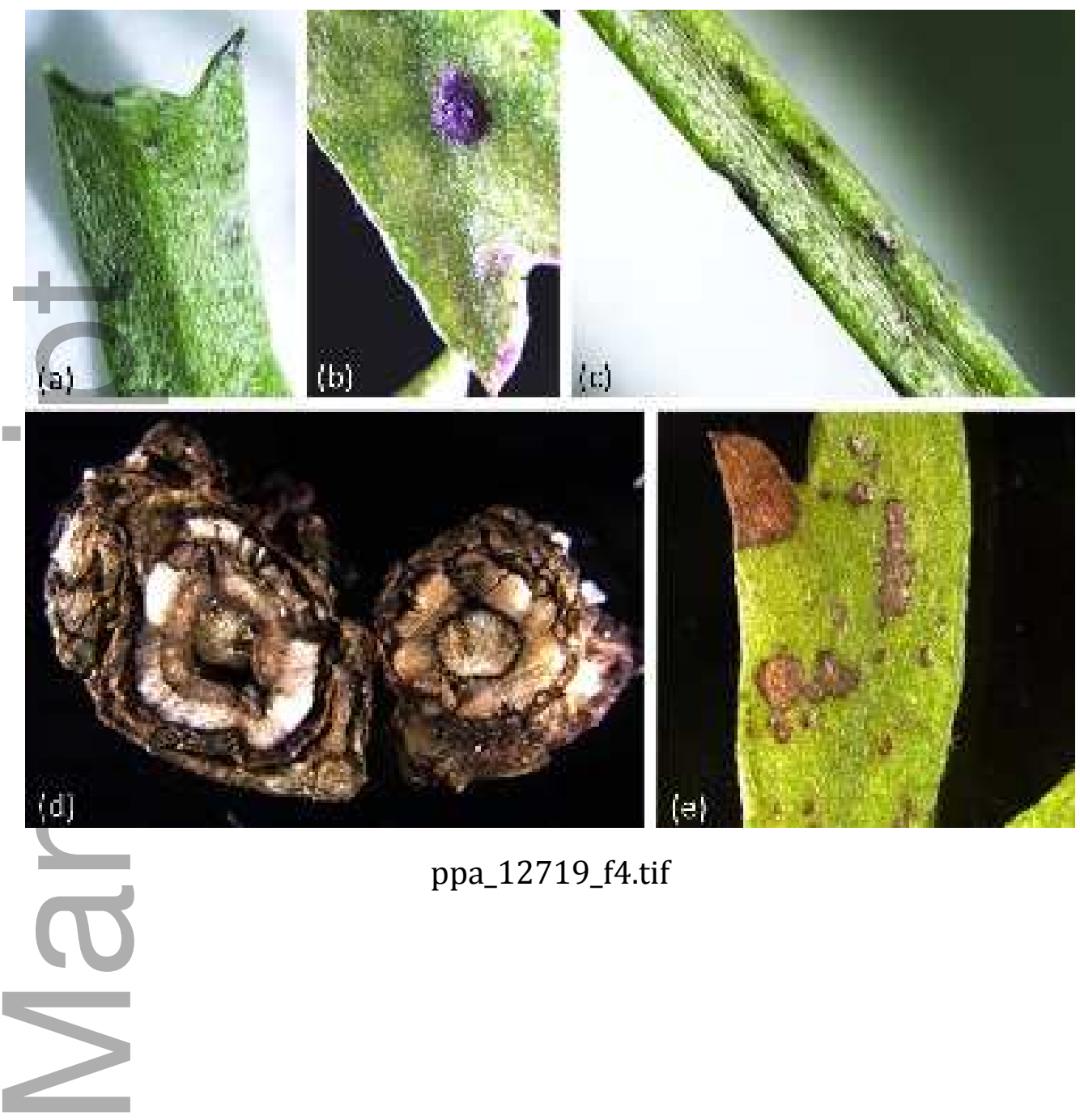

ppa_12719_f4.tif

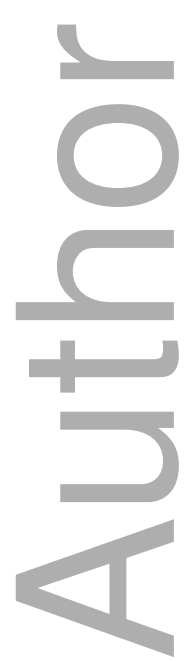



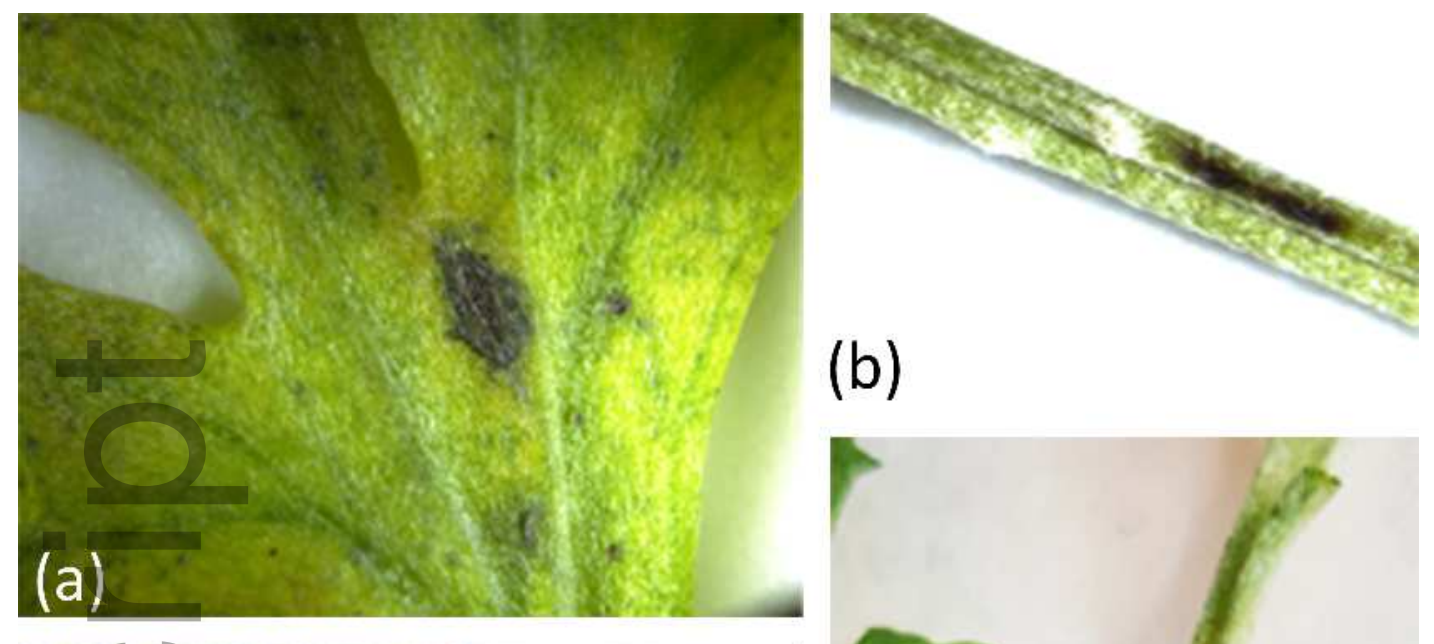

(b)
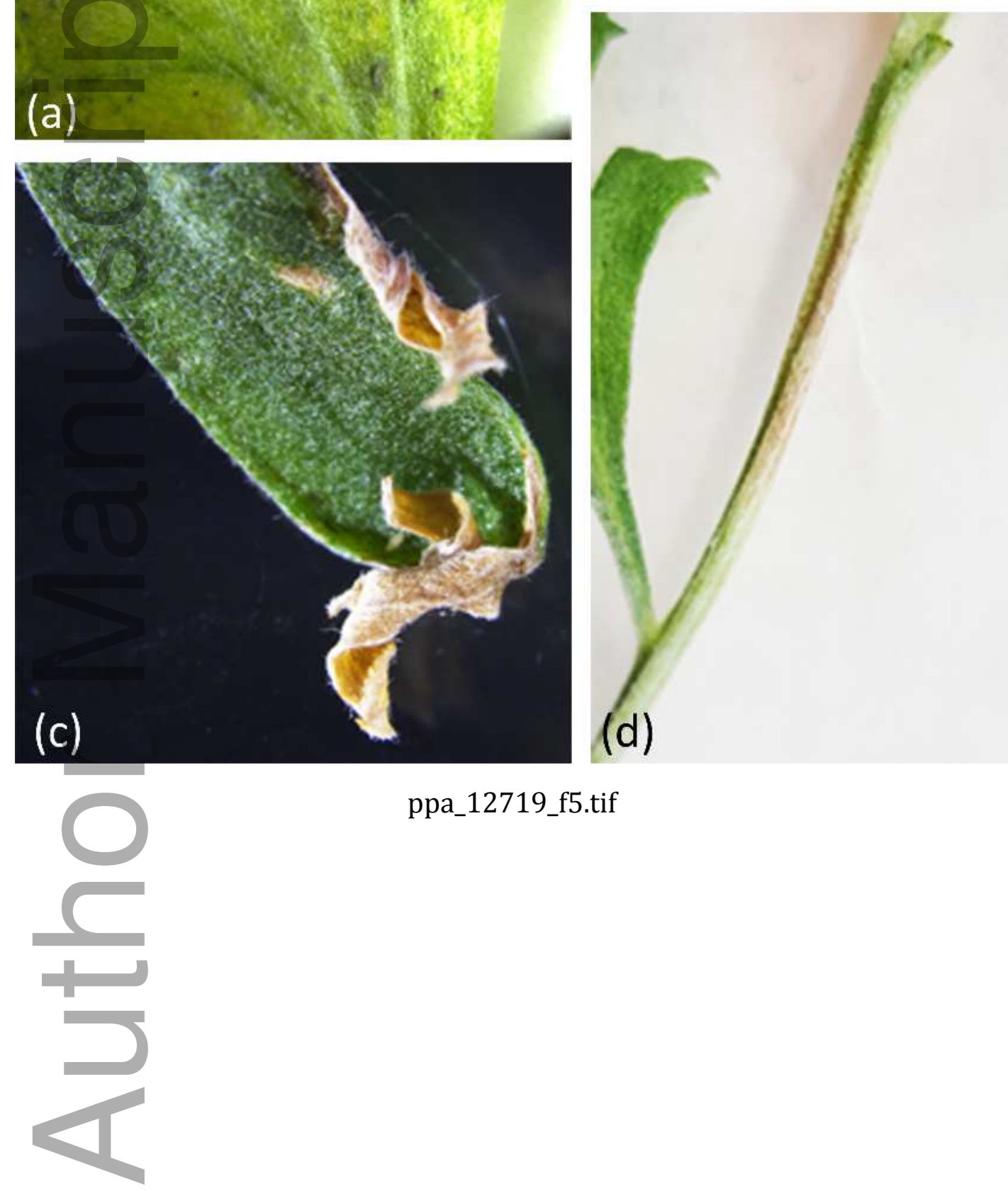

ppa_12719_f5.tif

ppa_12719_f5.tif 


\section{University Library}

\section{- M M N E R VA A gateway to Melbourne's research publications}

Minerva Access is the Institutional Repository of The University of Melbourne

Author/s:

Moslemi, A;Ades, PK;Crous, PW;Groom, T;Scott, JB;Nicolas, ME;Taylor, PWJ

Title:

Paraphoma chlamydocopiosa sp nov and Paraphoma pye sp nov., two new species associated with leaf and crown infection of pyrethrum

Date:

2018-01-01

Citation:

Moslemi, A., Ades, P. K., Crous, P. W., Groom, T., Scott, J. B., Nicolas, M. E. \& Taylor, P. W. J. (2018). Paraphoma chlamydocopiosa sp nov and Paraphoma pye sp nov., two new species associated with leaf and crown infection of pyrethrum. PLANT PATHOLOGY, 67 (1), pp.124-135. https://doi.org/10.1111/ppa.12719.

Persistent Link:

http://hdl.handle.net/11343/292962 